\title{
Bioavailable iron produced through benthic cycling in glaciated Arctic fjords (Svalbard)
}

Katja Laufer ( $\nabla$ katja.laufer@hotmail.de )

GEOMAR Helmholtz Centre for Ocean Research Kiel https://orcid.org/0000-0003-4779-1703

Alexander Michaud

Aarhus University

Markus Maisch

Tübingen University

James Byrne

Tübingen University

Andreas Kappler

University of Tübingen

Molly Patterson

Binghamton University

Hans Røy

Aarhus Univerisity

Bo Barker Jørgensen

Aarhus University

\section{Article}

Keywords: Arctic, Iron, Sediment, Glacier, Svalbard

Posted Date: August 21st, 2020

DOI: https://doi.org/10.21203/rs.3.rs-55627/v1

License: (c) (1) This work is licensed under a Creative Commons Attribution 4.0 International License. Read Full License

Version of Record: A version of this preprint was published at Nature Communications on March 1st, 2021. See the published version at https://doi.org/10.1038/s41467-021-21558-w. 


\section{Bioavailable iron produced through benthic cycling in}

\section{glaciated Arctic fjords (Svalbard)}

Katja Laufer ${ }^{*}, 2$, Alexander B. Michaud ${ }^{2,3}$, Markus Maisch" ${ }^{4}$, James M. Byrne ${ }^{4,5}$, Andreas Kappler ${ }^{2,4}$, Molly O. Patterson ${ }^{6}$, Hans Rø $\mathrm{y}^{2}$, Bo Barker Jørgensen ${ }^{2}$

${ }^{1}$ Now: GEOMAR, Helmholtz Centre for Ocean Research Kiel, Germany

${ }^{2}$ Center for Geomicrobiology, Department of Biology, Aarhus University, Denmark

${ }^{3}$ Now: Bigelow Laboratory for Ocean Sciences, Maine, USA

${ }^{4}$ Center for Applied Geosciences, University of Tübingen, Germany

${ }^{5}$ Now: School of Earth Sciences, University of Bristol, Wills Memorial Building, Queens Road, Bristol BS8 1RJ, United Kingdom

${ }^{6}$ Department of Geological Sciences and Environmental Studies, Binghamton University, New York, USA

*Corresponding Author

Katja Laufer. Wischhofstraße 1-3, 24148 Kiel, Germany. Tel.: 0049431600 1267. E-mail: klaufer@geomar.de

ORCIDs

KL (http://orcid.org/0000-0003-4779-1703), ABM (https://orcid.org/0000-0001-5714-8741), JMB (0000-00024399-7336), BBJ (0000-0001-9398-8027)

\section{Keywords}

Arctic, Iron, Sediment, Glacier, Svalbard

\section{Author Contributions}

$\mathrm{KL}$ and $\mathrm{ABM}$ designed the study, performed fieldwork, laboratory measurements of SRR, analyzed data and wrote the manuscript. KL performed laboratory measurements and data analysis of Fe and $\mathrm{Mn} . \mathrm{MM}, \mathrm{JMB}$ and AK performed Mössbauer spectroscopy measurements, analyzed Mössbauer spectroscopy data, and wrote the sections regarding Mössbauer spectroscopy. MOP performed particle size measurements, analyzed the data and wrote the sections regarding particle size analysis. HR and BBJ supervised $K L$ and $A B M$ and performed fieldwork. All authors reviewed the manuscript. 


\section{Abstract}

30 The Arctic has the highest warming rates world-wide. Glaciated fjord ecosystems, which are known hotspots of 31 carbon cycling and burial, are predicted to be extremely sensitive to this warming. Glaciers are important 32 sources of iron, an essential nutrient for phytoplankton, to high-latitude marine ecosystems. However, up to $3395 \%$ of the glacially-sourced iron settles in sediments close to the glacial source. We found that only $0.6-12 \%$ of 34 the total glacially-sourced iron is potentially bioavailable. Our results also show that biogeochemical cycling in 35 fjord sediments converts the unreactive glacial iron into more reactive and bioavailable phases, leading to an 36 up to 9-fold increase in the amount of potentially bioavailable iron. Arctic fjord sediments therefore likely are 37 an important source of bioavailable iron. However, once glaciers retreat onto land, the flux of iron from 38 sediments into the water column is reduced, such that glacial retreat could exacerbate iron limitation in polar 39 oceans. 


\section{Introduction}

Iron is an essential nutrient for phytoplankton and limits primary productivity across $30-40 \%$ of the global ocean area ${ }^{1,2}$. While the Arctic Ocean is generally not considered to be iron-limited ${ }^{3}$, recent research indicates that regional iron-limitation exists and could increase with future climate change ${ }^{4-7}$. The Arctic regions are warming 2-3 times faster than the global average ${ }^{8,9}$. Arctic glaciated fjord ecosystems, which are known hotspots of carbon cycling and burial, are predicted to be extremely sensitive to this warming ${ }^{10,11}$.

Glaciers and ice-sheets are a primary iron source to the oceans, along with rivers, hydrothermal vents, and aeolian dust ${ }^{12-15}$. The majority of glacially-derived iron is in the particulate form or will rapidly become particulate once in contact with oxic and saline fjord water due to oxidation and flocculation reactions ${ }^{15-20}$, resulting in up to $95 \%$ of glacially-sourced iron settling to fjord sediments after entering the marine environment. However, the amount and physical and chemical characteristics of glacial iron that is delivered to Arctic fjords, as well as its fate, remain poorly constrained ${ }^{12,21}$. Speciation, particle size, surface area, and crystallinity are physical and chemical characteristics of iron minerals that determine if it is available for biological processes. Ascorbate has been shown to selectively extract poorly crystalline, highly reactive Fe(III) ${ }^{22}$, which is potentially bioavailable for phytoplankton ${ }^{18,23,24}$ and favorable for microbial reduction ${ }^{25,26}$. Thus, in the context of benthic cycling and early diagenesis, we define ascorbate-extractable Fe(III) as reactive and bioavailable iron (FeR). While previous studies have focused on the delivery of iron to marine ecosystems by icebergs ${ }^{27,28}$ and proglacial meltwater ${ }^{15,29}$, these sources contain low amounts of FeR $\left(0.75-26 \mu \mathrm{mol} \mathrm{gdw}^{-1}\right)$, compared to what has been reported for fjord sediments $\left(9.5-176 \mu \mathrm{mol} \mathrm{gdw}^{-1}\right)^{26,30}$. However, it is not well understood how benthic processes in fjord sediments are impacted by the input of glacial iron and, conversely, how benthic processes impact the physical and chemical characteristics and the fate of glacially-derived iron. Understanding what happens after glacially-derived iron settles to fjord sediments is crucial to evaluate if these sediments function as net sources or sinks of bioavailable iron.

Iron is not simply buried in marine sediments after deposition. An interplay of biotic and abiotic reactions, which drive the benthic biogeochemical iron $\mathrm{cycle}^{31}$, change the speciation, mineralogy, and physical and chemical characteristics of iron ${ }^{31-33}$. The reduction of $\mathrm{Fe}(\mathrm{III})$ in sediments is catalyzed by abiotic redox reactions with sulfide or organic matter, and by biotic redox reactions mediated by microorganisms ${ }^{31}$. Microorganisms preferentially reduce reactive, poorly crystalline Fe(III) minerals during organic carbon mineralization due to the high energy yield and relatively large surface area. However, over longer timescales microorganisms can also reduce $\mathrm{Fe}(\mathrm{III})$ in highly crystalline Fe(III) minerals, such as hematite or iron in silicates ${ }^{25,34-36}$. $\mathrm{Fe}(\mathrm{II})$ is 
oxidized by abiotic reactions with oxygen, $\mathrm{Mn}(\mathrm{IV})$-oxides or reactive nitrogen species and by biotic reactions mediated by microorganisms. Microorganisms are thought to preferably oxidize dissolved Fe(II) with oxygen or nitrate as electron acceptor or coupled to anoxygenic photosynthesis ${ }^{31}$, while producing highly reactive, poorly crystalline, biogenic Fe(III) minerals ${ }^{37,38}$. However, solid-phase Fe(II) in silicate or sulfide minerals, which are known to be important in glacial systems $s^{39,40}$, is also available for oxidation by microorganisms ${ }^{41,42}$. The complexity of the benthic iron cycle and its interconnections to many other element cycles make it important, as changes to the iron cycle create a cascade of impacts on the availability of phosphate and other nutrients and, most importantly, the cycling and burial of carbon.

With ongoing warming, glacier termini are retreating from the sea onto land, which will lead to changes in the export, processing, and delivery of glacially-derived material ${ }^{43}$. Glacial retreat also causes changes in water circulation and primary productivity in the fjord ecosystem ${ }^{44-47}$. Despite the fact that fjords are significant sinks of carbon ${ }^{11}$ and hotspots of biogeochemical cycles $^{48,49}$, it remains unknown how glacial retreat onto land will impact the processing of glacially-sourced iron in fjord sediments along with its speciation, transport and bioavailability. If iron cycling is sensitive to glacial retreat, then this could contribute to increasing iron limitation in the Arctic Ocean and thus have a profound effect on primary productivity and carbon cycling.

The aim of this study was to understand the effects of glacially-derived iron on benthic processes in fjord sediments, quantify how these processes change the characteristics of glacially-derived iron, and assess the potential impacts on iron bioavailability and export to the water column. We quantified the amount and reactivity of iron in different glacial sources (icebergs, proglacial rivers, proglacial plumes) and determined the spatial and depth distribution of FeR in high-resolution transects in three contrasting Arctic fjords of Spitsbergen, Svalbard (Figure 1). The transects reach from the head of the fjord, close to the glacial source, to the mouth of the fjord, where it opens to the ocean. Of the three studied fjords, Kongsfjorden and Lilliehöökfjorden both have large marine-terminating glaciers at their head (Figure 1a-c) but possess differing catchment geology. Dicksonfjorden (Figure 1a and d) has land-terminating glaciers with a catchment geology similar to Kongsfjorden. Thus our study sites have the ability to provide insight into the impact of bedrock geology and glacial retreat on benthic biogeochemical processes.

\section{Results and Discussion}

FeR in glacial sources. Particulate material collected from a variety of glacial sources in Kongsfjorden had a high total iron content $\left(320-1400 \mu \mathrm{mol}\right.$ total $\mathrm{HCl}$ extractable Fe $\mathrm{gdw}^{-1}$, Table S1), which is within the range 
previously reported for glacial sources worldwide ${ }^{13,50,51}$. However, iron minerals in these glacial sources were mostly poorly reactive and the amount of reactive ion $\left(\mathrm{M}_{(0)}\right)$ was only $30.9 \pm 4.6,28.1 \pm 12.9$, and $8.1 \pm 6.1 \mu \mathrm{mol}$ $\mathrm{gdw}^{-1}$ as determined by ascorbate time-course (AFeR) extractions from glacial plume, meltwater river, and iceberg samples, respectively ${ }^{26}$ (Figure $2 \mathrm{a}$, Table S1). The results of the AFeR extractions are consistent with differences in Fe-mineralogical composition detected by ${ }^{57} \mathrm{Fe}$ Mössbauer spectroscopy, showing that iron in a Kongsfjorden plume sample had a relative abundance of $17.8 \pm 1.6 \%$ hematite, whereas material from a Kongsfjorden iceberg contained about twice as much hematite, accounting for $41.3 \pm 1.9 \%$ of the iron pool (Figure S1, Table S2). These data corroborate results of Raiswell and coworkers ${ }^{18}$, who showed that FeR produced by chemical and biological weathering in subglacial systems ${ }^{18,52,53}$ gets slowly converted into less reactive phases such as goethite or hematite in glacial ice, which may explain the higher proportion of hematite found in the icebergs. Given the low amount of FeR in the glacial sources, only a small fraction (0.6-12\%) of glacially derived iron is immediately available for microbial reduction in the sediment ${ }^{26}$ and potentially bioavailable for phytoplankton ${ }^{23}$. These data are in agreement with previous results showing a high total iron content, but low amount of FeR in glacial sources of Kongsfjorden ${ }^{18,54,55}$. Microbial iron reduction time-course (MFeR) extractions, directly measuring the microbial reducibility of iron in glacial source material ${ }^{26}$, yielded about two times higher amounts of FeR, compared to the AFeR extractions, whereas the relative differences between the samples were similar (Table S1).

Samples from the same type of glacial source in Kongsfjorden generally had a similar amount of reactive iron, but there were some exceptions (Table S1, Figure S2). The meltwater river samples from Austre Lovenbreen from 2017 contained a higher (by 78\%) amount of FeR compared to the 2018 sample (Table S1). Also the iceberg and meltwater plume samples from Kongsvegen contained a higher (by $263 \%$ and $30 \%$, respectively) amount of reactive Fe compared to the samples from Kronebreen. The differences in iron amount and reactivity found from Kongsvegen and Kronebreen are in large part due to the different bedrock types underlying these two large glaciers. Kongsvegen overrides Carboniferous-Permian age limestones and dolostones, whereas Kronebreen overrides iron-rich, Devonian age red sandstones ${ }^{56}$, also resulting in strikingly different colors (Figure S3). While the amount of FeR varied in some cases, even within one type of glacial source, the parameters determined in AFeR experiments (apparent rate constant, heterogeneity, and initial rate) were still similar for samples from the same type of glacial source (Figure 2), implying that samples from the same type of glacial source contained FeR with similar mineral composition, as can also be seen from the similar shape of the dissolution curves (Figure S2). 
The parameters determined in AFeR extractions enable a detailed characterization of not only the iron reactivity, but also the composition of the iron mineral pool. The heterogeneity parameter quantifies the heterogeneity of reactivities in iron minerals extracted by ascorbate. This parameter can also be thought of as the diversity of ascorbate-extractable iron minerals with different reactivities present. The highest heterogeneity was found for particulates from the plume at the head of Kongsfjorden (1.83 \pm 0.6 , Figure $2 \mathrm{~d}$ ), indicating heterogeneity in the mineral composition with a range of corresponding reactivities. The lowest heterogeneity was found for

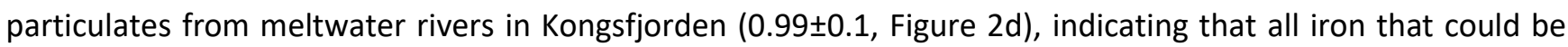
extracted by ascorbate had a relatively similar reactivity and likely homogeneous iron mineral composition. These results indicate that glacial iron transported by proglacial rivers gets sorted or even chemically or physically modified, such that a uniform type of reactive iron mineral is supplied to Kongsfjorden. The initial rate parameter determined in AFeR extractions is the best measure of biological availability and iron reducibility ${ }^{26}$, as it takes into account the amount $\left(\mathrm{M}_{(0)}\right)$ and reactivity (apparent rate) of FeR. Particulates collected from icebergs had the lowest initial rate (reducibility) of all glacial sources in Kongsfjorden $\left(1.1 * 10^{-3} \pm 0.8^{*} 10^{-3} \mu \mathrm{mol} \mathrm{gdw}^{-1} \mathrm{~s}^{-1}\right.$, Figure $\left.2 \mathrm{~b}\right)$. The highest reducibility of glacial source material was found in the Kongsfjorden glacial plume, which had an $800 \%$ higher initial rate compared to the average of the icebergs $\left(8.8^{*} 10^{-3} \pm 2.9 * 10^{-3} \mu \mathrm{mol} \mathrm{gdw}^{-1} \mathrm{~s}^{-1}\right.$, Figure 2 , Table S1). This highlights that glacial meltwater emanating as the plume in front of Kronebreen, contains FeR that was produced by subglacial weathering. On the other hand, icebergs contain iron which has aged and become less reactive while transported in glacial ice until delivered to the fjord through iceberg calving ${ }^{18}$. Even the highest reducibility of the Kongsfjorden glacial source samples was ten times lower than the previously highest reported values of Kongsfjorden sediment ${ }^{26}$ (Figure 2).

Particulates collected in the plume of the meltwater river at the head of Dicksonfjorden (Dicksonelva, Figure 1) had only $20 \%$ the amount of FeR that was found in the Kongsfjorden plumes and meltwater rivers. The amount of FeR in Dicksonelva particulates $\left(5.95 \mu \mathrm{mol} \mathrm{gdw}{ }^{-1}\right.$, Table S1, Figure 2a) similar to the average of the Kongsfjorden iceberg samples. Also the reactivity and reducibility of Dicksonelva particulates was most similar to the lowest values that we found for the icebergs in Kongsfjorden. The reducibility of Dicksonelva particulates was only a fourth of what we measured for Kongsfjorden river particulates and 25-times lower compared to the proglacial plume in Kongsfjorden. The heterogeneity parameter (1.31) was higher than the meltwater rivers in Kongsfjorden (Table S1), showing that the FeR in the Dicksonelva sample has a broader range of reactivities compared to the meltwater rivers in Kongsfjorden. Dicksonelva is very different from the meltwater rivers in Kongsfjorden, as it enters the fjord in a large delta with an intertidal mudflat ${ }^{57}$, which seems to affect the 
transport and/or production of FeR. Previous studies have concluded that sediment transport in meltwater rivers will transform minerals into more reactive phases due to increased weathering ${ }^{58}$. This does not seem to hold true for Dicksonelva.

The differences in FeR amount and reducibility that we found for particulates from glacial sources in Kongsfjorden and Dicksonfjorden contain a paucity of FeR, independent of glacial regime or source type. Still, there were differences in the reactivity, heterogeneity, and amount of FeR delivered by the different types of glacial sources, which add to predicted effects of glacial retreat with the potential to impact biogeochemical cycles such as the linked iron and carbon cycles within the downstream fjord sediments ${ }^{43,44,46}$.

The reactivity and spatial distribution of FeR in Kongsfjorden sediment. The amount and reducibility of FeR at the fjord head (KF1; Figure 1) was the lowest (Figure 3, Table S3) of all surface sediment samples within the Kongsfjorden transects. In fact, the amount and reducibility of FeR at KF1 are similar to the average of Kongsfjorden glacial sources and implies that there is little processing of iron upon sedimentation at the head of the fjord (Figure $2 \mathrm{a}$ and $\mathrm{b}$ ). However, the amount and reducibility of FeR in surface sediment in Kongsfjorden increased by 9-fold and 19-fold, respectively, at the station furthest away from the fjord head (KFa7; Figure 2a and b, Figure 3, Table S3). A similar increase in FeR amount and reducibility over distance was found in the northern transect (KF1 to KFb5) of Kongsfjorden (Figure 3). These increases are exponential as seen from the linear increase in the semi-log-plot (Figure 3) and an $\mathrm{R}^{2}$ of 0.96 and 0.94 for the transects going towards KFa7 and $\mathrm{KFb5}$, respectively, when fitting an exponential model through the data (Table S4). Further, time-course extractions using a microbial pure culture $\left(\mathrm{MFeR}^{26}\right)$ showed even more pronounced differences in the reducibility of FeR at the surface of station KFa7 and KFb5 compared to all the sources (Figure 3, Table S5). These increases are either produced by preferential transport of the smallest, most reactive particles or by processing of the iron upon sedimentation.

AFeR extractions showed that FeR in the transects became more heterogeneous over the first few km distance, likely due to the glacial sources containing FeR with different reactivities and authigenic production of reactive Fe within the sediment. Further out in the fjord, FeR became more homogeneous again, reaching values even lower than at KF1, indicating the presence of a uniform pool of highly reactive iron (Table S3, Figure S4). The increase in amount and reducibility as well as the changes in the heterogeneity of FeR with increasing distance from the fjord head imply that significant processing of iron occurred after sedimentation at stations further away from the fjord head, likely through microbial dissimilatory iron reduction or interactions with sulfide ${ }^{30,58 .}$ 
It seems as if a homogenous pool of highly reactive FeR is produced in the surface sediments as distance from the glacial source increases (Figure 3, S5-7).

These results are consistent with ${ }^{57} \mathrm{Fe}$ Mössbauer spectroscopy, which showed that the relative abundance of hematite in KF1 was $21.1 \pm 1.3 \%$, similar to the Kronebreen plume. The abundance of hematite in the surface sediment of KFa7 (10.3 $\pm 2.1 \%)$ was only half that of KF1 (Figure S1, Table S2). This distribution of iron minerals with different crystallinities could be caused by the transport of the finest and most reactive particles to the more distant stations, which would also explain the higher iron reactivity that we measured in AFeR extractions. However, the reducibility of reactive iron in KF7 surface sediment is higher than any value measured in the plume, and also notably higher (by $860 \%$ ) than the average of all glacial sources (Figure $2 \mathrm{~b}$, Table S1, S3). Taken together, these data indicate that the abundant iron mineral species were more dominated by less crystalline, more reactive iron phases further from the head of the fjord and that they might be authigenic.

The impact of contrasting catchment geology on the spatial distribution of FeR. Lilliehöökfjorden possesses differing catchment geology than Kongsfjorden, yet the same increase in FeR amount and reducibility over distance from the fjord head was found, reaching a maximum of $89 \mu \mathrm{mol} \mathrm{gdw}^{-1}$ at LF8, which is an increase of $390 \%$ within the $23 \mathrm{~km}$ transect. (Figure 3). The reducibility also increased by $430 \%$ in our Lilliehöökfjorden transect (Figure 3, Table S3). The Lilliehöökfjorden FeR pool develops in a manner similar to the two transects in Kongsfjorden where a diverse pool of FeR becomes progressively more uniform in composition with distance from the fjord head (Figure S4). The MFeR extractions detected a similar increasing trend in FeR amount and reducibility in Lilliehöökfjorden (Figure 3, Table S5). The trend of increasing FeR amount and reducibility is interrupted where Möllerfjorden and Lilliehöökfjorden merge (between LF6 and LF7; Figure 1, 3), with Möllerfjorden likely supplying less reactive iron to the sediments. Also changes in pore water Fe and Mn were found where these two fjords merge, with maximum dissolved Fe(II) (dFe(II)) concentrations decreasing and maximum dissolved $\mathrm{Mn}(\mathrm{dMn})$ concentrations increasing at station LF6, compared to the stations closer to the fjord head (Figure S8).

No hematite could be identified by ${ }^{57} \mathrm{Fe}$ Mössbauer spectroscopy in Lilliehöökfjorden samples and the iron mineral composition was different from Kongsfjorden as expected from the contrasting bedrock and sediment color (Figure 1, Figure S9, Table S2). Collected spectra were similar for LF1 and LF5, with a higher proportion of $\mathrm{Fe}$ (III) towards the fjord mouth (LF5) compared to the fjord head (LF1). This increase in Fe(III) detected by ${ }^{57} \mathrm{Fe}$ Mössbauer spectroscopy gives an indication of the production of authigenic Fe(III) minerals in sediment further 
away from the fjord head and mirrors the trend found in AFeR extractions. Consequently, the oxidation of Fe(II) to $\mathrm{Fe}(\mathrm{III})$, by biotic or abiotic processes ${ }^{31}$, appears to be important for the production of FeR in Lilliehöökfjorden. The results from Mössbauer spectroscopy helped to support findings from the AFeR extractions but Mössbauer spectroscopy alone did not capture this distinct change in the amount and reactivity of FeR over distance from the glacier. This highlights the value of direct quantification of FeR amount and reactivity in AFeR and MFeR extractions.

In Kongsfjorden and Lilliehöökfjorden the amount and reducibility of FeR increased by up to 50 and $166 \%$, respectively, per $\mathrm{km}$ of distance from the fjord head independent of catchment geology (Figure 3 and S4). This pattern of increasing FeR amount with distance from the fjord head was also observed in two fjords in southwestern Svalbard ${ }^{58}$. Van Mijenfjorden and Van Kuelenfjorden in southern Spitsbergen, Svalbard drain different bedrock assemblages and reinforce the widespread nature of these FeR patterns in fjord sediments. The increases we observe in Kongsfjorden are statistically significant over the entire length of the transects (Table S4). For the Lilliehöökforden transect, the flattening off after station LF6, causes the increase in the amount of FeR over distance to have low significance and the increase in reactivity over distance to have no significance. If only the data until LF5 are included in the analysis, the increase in the amount and reactivity become statistically highly significant (Table S4). This again supports our hypothesis that Möllerfjorden outputs impact the Lilliehöökforden transect and represents the sensitivity of fjord sediments to nearby marineterminating glaciers. In conclusion, the increases of reactive Fe in fjord sediments toward the fjord mouth, irrespective of catchment of geology, reveals that there is a gradual transformation of unreactive glaciallyderived iron minerals towards higher reactivity and bioavailability.

FeR production through benthic cycling in fjord sediments. We propose that the main driving force transforming the unreactive glacially-derived iron into FeR is benthic cycling through an interplay of abiotic and biotic processes ${ }^{31}$ (Figure 4). These processes produce authigenic, poorly crystalline, highly-reactive and easily reducible FeR in the oxic sediment surface (Figure 5) through abiotic or microbially mediated oxidation of $\mathrm{dFe}(\mathrm{II})^{31}$. High concentration gradients with depth, driving a flux of dFe(II) into the oxic sediment layers, were found at all stations in Kongsfjorden and Lilliehöökfjorden (Figure 6). The source of dFe(II) is a combination of: (i) reductive dissolution of $\mathrm{Fe}$ (III) from $\mathrm{Fe}$ (III) (oxyhydr)oxides, (ii) oxidation of pyrite, originating from bedrock beneath the glacier ${ }^{49}$, and (iii) dissolution and oxidation of other Fe(II)-bearing minerals such as $\mathrm{Fe}(\mathrm{II})$ carbonates or primary silicates through microbial or abiotic weathering processes ${ }^{59,60}$ (Figure 4). Which of the possible dFe(II) sources is most important in the different fjord sediments is a function of the catchment 
geology, geochemical conditions, and microbial activity. Regardless of the source of dFe(II), Fe(II)-oxidation at the sediment surface produces authigenic Fe(III) minerals, and that process gets stronger towards the mouth of the fjord.

The strong gradient in FeR from fjord head to mouth is controlled by steep gradients in hydrology, biology, and geochemistry due to inputs of glacial material at the fjord head and the marine influence at the fjord mouth ${ }^{61-}$ 63. At the fjord head, high sedimentation rates of detrital material and low primary productivity within a thin photic zone 20,64 , lead to sediment with low TOC amount and high C: $N$ ratio of up to 70 (Table S6, Figure 7). Towards the fjord mouth TOC contents gradually increased, while C:N ratios decreased and approached a more marine-like signature (Table S6, Figure 7). The C:N gradient is a result of a higher proportion of old and refractory organic carbon of glacial origin and terrestrial material settling closer to the fjord head, while towards the mouth there is higher primary productivity in the fjord, leading to more fresh organic matter settling to the sediment ${ }^{65,66}$. Terrestrial organic carbon usually has $\mathrm{C}: \mathrm{N}$ values $>20^{67}$ with mosses and lichens reaching values of up to 79 and 207 , respectively ${ }^{68}$, while fresh marine organic matter usually has lower C:N values around 6-9 ${ }^{69}$. Similar trends of increasing TOC and decreasing C:N with distance from the fjord head were reported previously for Svalbard fjords ${ }^{58,70-72}$ and high C:N values of up to 50 have also been reported for Greenlandic fjords ${ }^{73}$. The $\mathrm{C}: \mathrm{N}$ ratio is a measure of the quality of the organic matter and how readily it can be respired by benthic microbial communities. Therefore, sediments close to glaciers can sustain only moderate activity of Fe(III)- or sulfate-reduction due to the low amount and refractory characteristics of the organic carbon (Figure 7). Further from the glacier, the sedimentation rate of inorganic detrital material decreases and primary productivity in the water column increases, producing sediment with a higher TOC amount and lower $\mathrm{C}: \mathrm{N}^{62,74,75}$. This creates favorable conditions for Fe-cycling, as the organic carbon can support higher rates of microbial Fe(III) reduction and sulfate reduction, both leading to the production of dFe(II).

Based on these results for TOC and C:N, we expect SRR to increase concurrent with the increase in TOC and the decrease in C:N. However, depth-integrated rates of SRR in Kongsfjorden and Lilliehöökfjorden at first increase, but then decrease further out in the fjord (Figure 7). This is likely caused by the consecutive increase in FeR along the transect, enabling Fe-reducers to compete favorably with sulfate-reducers (for more detailed discussion of SRR in relation to TOC and $\mathrm{C}: \mathrm{N}$, see supplemental information). Besides the increased activity of benthic iron cycling, the lower sedimentation rates in the outer part of fjords ${ }^{62,74}$ lead to a more abundant and active benthic fauna ${ }^{76}$, further intensifying benthic cycling ${ }^{77,78}$, and increased time for iron to be repeatedly cycled before it gets buried deeper in the sediment (Figure 8a). 
Sedimentation gradients in Arctic fjords caused by particle transport in freshwater lenses could explain the observed FeR gradients by carrying the finest and most reactive grains furthest ${ }^{20}$. However, we did not find evidence for long-distance transport of the finest and most reactive glacial iron in generating the observed gradient of FeR. Over $95 \%$ of the grain size distributions from surface sediment samples recovered along the transects are characterized by silt and clay $(<63 \mu \mathrm{m}$ or $4 \phi)$ (Figure S10). We found no systematic relationship between the percent of fine-grained material and the distance from the fjord head (Figure S10). Our results corroborate other observations that the majority of the suspended material in fjords supplied from marine or land-terminating glaciers does not reach further than $7 \mathrm{~km}$ from the source and that flocculation causes also suspended colloidal and nano-particulate material to quickly settle from the water column ${ }^{20,79}$. For more detailed interpretation of the grain size analysis, see supporting information. Thus, the increase of FeR over distance cannot be explained as a function of the transport of small particles containing the most reactive Fe. The increase in reactivity through benthic iron cycling, also called "rejuvenation", has also been shown to be an important pathway for bioavailable iron production in continental margin sediments ${ }^{77,80,81}$. The steep gradients in FeR seem to be unique for glaciated fjord systems and we conclude that in glaciated arctic fjords the increasing intensity of benthic iron cycling, due to increased amount of labile organic carbon, and time before burial produce the observed gradients of FeR from fjord head to mouth.

The impact of glacial retreat on FeR distribution and Fe-export to the water column. The general pattern of increasing amount and reducibility of FeR with distance from the fjord head is also observed in Dicksonfjorden, which is fed only by land-terminating glaciers (Figure 1). The amount of FeR was only about half of what was found in Kongsfjorden and Lilliehöökfjorden at similar distances from the fjord head (Figure 3a). However, the reactivity of FeR was higher in Dicksonfjorden, such that the reducibility (initial rate) was within the same range as for Kongsfjorden and Lilliehöökfjorden (Figure 3b and S4, Table S3). We propose that, similar to Kongsfjorden and Lillihöökfjorden, benthic cycling is responsible for the increase in the amount and reducibility of FeR from head to mouth in Dicksonfjorden. In contrast to Lilliehöökfjorden and Kongsfjorden, where the amount of FeR $\left(\mathrm{M}_{(0)}\right)$ peaked at the sediment surface, the maximum concentration of FeR was never found at the sediment surface in Dicksonfjorden (Figure 5, Figure S4 and S11-S17, Table S3). At station DF1, the amount of FeR did not change significantly over sediment depth and at station DF3 and DF5 the maximum amount of FeR was found at 3-4 and 6-8 $\mathrm{cm}$ sediment depth with 38.3 and $70.7 \mu \mathrm{mol}$ gdw $^{-1}$, respectively (Figure 5, Figure S17, Table S3). We conclude that the production of FeR is not only independent of bedrock lithology, but also 
of glacial regime. However, the specific depth-distribution of FeR that we found in Dicksonfjorden might impact the potential for FeR release to the water column.

311 The subsurface peaks of FeR in Dicksonfjorden are likely caused by deeper penetration of oxidants (such as 312 oxygen, nitrate or $\mathrm{Mn}(\mathrm{IV})$-oxides; Table S7) and provide further evidence that the FeR is authigenic and not a 313 function of the fine grained and reactive material getting transported furthest. The presence of oxidants is evident from the absence of dissimilatory sulfate reduction, $\mathrm{dFe}(\mathrm{II})$, and $\mathrm{dMn}$ just above the depth where the maximum amount of FeR was found at station DF3 and DF5. This indicates that dFe(II) and dMn were oxidized within the top 3-5 cm of the sediment and could not reach the sediment surface at these stations. At station DF1, low SRR ( $\left.<1 \mathrm{nmol} \mathrm{cm} \mathrm{d}^{-3}\right)$ and dMn were found within the upper $4 \mathrm{~cm}$ of the sediment, but no dFe(II) was detected (Figure 6). Again, Dicksonfjorden is in contrast to Kongsfjorden and Lilliehöökfjorden where sediment sulfate reduction was active and $\mathrm{dFe}(\mathrm{II})$ and/or $\mathrm{dMn}$, could be detected within the upper $2 \mathrm{~cm}$ of the sediment at all stations (Figure 5 and 6). The deeper penetration of oxidants in Dicksonfjorden sediments is likely caused by the generally lower primary productivity in fjords with land-terminating glaciers as they lack glacial upwelling, which is known to entrain nutrient-rich bottom water and transport it up to the photic zone where it supports primary productivity ${ }^{44-47}$. The smaller increase in TOC is likely due to diminished primary productivity in the Dicksonfjorden water column and leads to a smaller increase in TOC content of the sediment with distance from the head of the fjord compared to Kongsfjorden and Lilliehöökfjorden (Figure 7a, Table S6). The lower TOC content also led to depth-integrated SRR that stayed low over the entire transect (Figure 7b). Consequently, the sediment microbial community is less active, oxidants penetrate deeper into the sediment and prevent dFe(II) from reaching the sediment surface to fuel authigenic Fe(III) production or from diffusing into the overlying water column .

The production of authigenic, reactive Fe(III) at the sediment-water interface ${ }^{82,83}$, and the diffusion of dFe(II) across the sediment-water interface ${ }^{84}$, have been shown to be important factors for Fe-transfer into the water column. We propose that there is a decreased potential for Fe-flux to the water column in Dicksonfjorden compared to Kongsfjorden or Lilliehöökfjorden because authigenic FeR is produced at several $\mathrm{cm}$ sediment depth and $\mathrm{dFe}(\mathrm{II})$ did not reach the sediment surface (Figure 8). The deepening of the iron cycle is an additional negative feedback mechanism on primary productivity in high-latitude marine systems when glaciers retreat onto land. While Kongsfjorden and Lilliehöökfjorden are potentially important sources of FeR to the water column, we conclude that when glaciers retreat onto land, benthic iron cycling is restricted to deeper sediment layers and reduces the source strength of FeR or dFe(II) from the sediment to the overlying water column and, 
ultimately, the open ocean (Figure 8b). As the iron and carbon cycles are intimately linked ${ }^{44,46}$, not only by primary production but also by carbon remineralization, glacial retreat may impact both the biological carbon pump and the function of sediments as carbon sinks ${ }^{11}$.

\section{Conclusions}

343 To improve our understanding of iron cycling in the ocean and production of essential bioavailable iron for primary production, it is fundamental to know the sources and fate of iron along the continental margins. We show that the amount and reactivity of FeR in glacially-derived material is low. While fjords were previously expected to reduce glacial iron delivery to the ocean ${ }^{18}$, we show that fjord sediments are a biogeochemically active interface in which glacially-sourced, unreactive iron is transformed into potentially bioavailable FeR through benthic cycling. Our results show that sediments at the fjord mouth contain bioavailable FeR that could be a source of iron to the marine shelf and open ocean environments, thereby promoting primary productivity. Moreover, the study highlights the impact of glacial retreat on biogeochemical processes in fjord sediments that may reduce their ability to serve as a source of iron for primary production in the Arctic Ocean.

\section{Material and Methods}

Field sites, sampling and processing of fjord sediment and glacial source material. We sampled fjord sediment and particulate material from glacial sources in three fjords (Kongsfjorden, Lilliehöökfjorden and Dicksonfjorden) located on the west coast of Spitzbergen, the largest island of the Svalbard archipelago (Figure 1). For more detailed description of the field sites see supplemental information.

Fjord Sediment was sampled at 11 sites in Kongsfjorden and 9 sites in Lilliehöökfjorden in June and July 2017, 2 sites in Lilliehöökfjorden in July 2018, and 5 sites in Dicksonfjorden in August 2018 aboard MS Teisten or MS Farm (Table S8, Figure 1). Sediment was retrieved with a Haps corer ${ }^{85}$ and sub-sampled aboard the ship using $2.8 \mathrm{~cm}$ (for SRR measurements) or $6 \mathrm{~cm}$ (for pore water and solid-phase geochemistry) diameter acrylic coring tubes. Sediment was stored at $4^{\circ} \mathrm{C}$ until further processing within 2 days after sampling.

Glacial source material was sampled in Kongsfjorden in June and July 2017, and July 2018. In total we collected 7 pieces from individual icebergs with embedded sediment (Figure S16), 4 samples of glacial plume water in front of the $\mathrm{KB} / \mathrm{KV}$ calving front, and 6 samples of meltwater from rivers along the southern and northern shore of Kongsfjorden (Table S9, Figure 1). The material from the meltwater rivers was collected directly at their mouth before entering the fjord. Material from the Dicksonelva plume at the head of Dicksonfjorden was sampled in August 2018 (Table S9). 
The distances of the stations relative to the main glacial source was determined by geospatial analysis using qGIS (v. 3.10). We used the imagery seen in Figure 1 to measure the distance from the glacier terminus to the GPS determined sample point. The imagery was collected $\sim 1$ month after our samples were collected and represented the glacial terminus at the time of sample collection.

Processing and subsampling of sediment cores. The $6-\mathrm{cm}$ wide subcores were sliced in an anoxic glove bag under $\mathrm{N}_{2}$ atmosphere $\left(<0.5 \%\right.$ atmospheric $\mathrm{O}_{2}$ concentration, checked with a trace-range optical oxygen sensor TROXROB10 connected to a Firesting $\mathrm{O}_{2}$-meter, Pyroscience). The cores were processed outside the laboratory at ambient temperature $\left(4-8{ }^{\circ} \mathrm{C}\right)$ using the technique of Keimowitz et al. ${ }^{86}$ with slight modifications as described in detail by Michaud et al. ${ }^{30}$. All plasticware used for subsampling was made anoxic by placing the plasticware and an oxygen scrubber (AnaeroGen, ThermoFischer) in a heat-sealed gas-tight plastic bag (Escal Neo, high gas barrier bag, Mitsubishi Gas Chemical Co., Inc.) for at least $24 \mathrm{~h}$. The sediment cores were sliced into 1-3 cm sections down to a depth of $13 \mathrm{~cm}$. After each section was homogenized, subsamples of sediment were taken for (i) Fe extractions, (ii) determination of porosity, water amount, TOC and TN, and (iii) pore water geochemistry. The subsamples for Fe extractions, porosity, water amount, TOC and TN were immediately frozen at $-20^{\circ} \mathrm{C}$. After closing the centrifuge tubes inside the glove bag under $\mathrm{N}_{2}$ atmosphere, the pore water samples were centrifuged for $15 \mathrm{~min}$ at $4000 \mathrm{rpm}$ outside the glove bag. The tubes were immediately returned to the glove bag after centrifugation, and the supernatant was filtered by centrifugation ( 5 minutes, 14000 $\mathrm{rpm}$ ) in spin filters (0.45 $\mu \mathrm{m}$ nylon membrane, Norgen Biotek). For dissolved Fe and $\mathrm{Mn}$ analysis an aliquot of the filtrate was acidified $(\mathrm{HCl}, 1 \mathrm{M}$ final concentration) and the remaining was used for sulfate quantification. All pore water samples were stored at $4^{\circ} \mathrm{C}$ in the dark until analysis.

Processing and subsampling of glacial source material: Particulate material was extracted from plume and river-water by centrifugation (15 min., 3000xg). Samples of sediment-loaded icebergs were first rinsed with milliQ water on the exposed surfaces, then molten inside a clean plastic bag before centrifugation. In all cases, the pellets were collected and frozen at $-20^{\circ} \mathrm{C}$ until analysis.

Pore water chemistry: Dissolved Fe(II) and $\mathrm{Mn}$ in the pore water were measured spectrophotometrically by the ferrozine assay ${ }^{87}$ and the formaldoxime assay ${ }^{88,89}$, respectively. Both assays were performed in 96 -well plates and the absorbance was measured at $562 \mathrm{~nm}$ for Fe(II) and $450 \mathrm{~nm}$ for $\mathrm{Mn}$ with a plate reader (FLUOstarOmega, BMG Labtech). The formaldoxime assay was adapted, according to Otte ${ }^{90}$, to exclude 
interference from the high $\mathrm{Fe}^{2+}$ amount in the pore water ${ }^{91}$. Sulfate concentration in pore water was quantified on 1:100 diluted samples using suppressed ion chromatography (Dionex). Some of the pore water chemistry data is already published ${ }^{26}$. For which stations this is the case is stated in Table S8.

Sulfate reduction rate measurements: Sulfate reduction rates (SRR, $\mathrm{nmol} \mathrm{cm} \mathrm{d}^{-1}$ ) were determined by injecting ${ }^{35} \mathrm{SO}_{4}{ }^{2-}$ into intact, $20-25 \mathrm{~cm}$ long , $2.8 \mathrm{~cm}$ diameter sediment cores ${ }^{92}$. Fifty $\mathrm{kBq}$ of carrier-free ${ }^{35} \mathrm{~S}-$ $\mathrm{SO}_{4}{ }^{2-}$ was injected at $1 \mathrm{~cm}$ depth intervals through ports sealed with polyurethane-based elastic sealant (Sikaflex $\left.{ }^{\circ}-11 \mathrm{FC}^{+}, \mathrm{Sika}\right){ }^{93}$. After 10 to 14 hours of incubation at near in-situ temperature $\left(2^{\circ} \mathrm{C}\right)$, the cores were sliced in $1 \mathrm{~cm}$ sections, which were added immediately to $10 \mathrm{ml}$ of $10 \%$ zinc acetate and homogenized by vortexing. The zinc acetate-fixed samples were stored at $-20^{\circ} \mathrm{C}$ until analysis. The cold chromium method ${ }^{93}$ was used to separate radiolabeled total reduced inorganic sulfur (TRIS) from the sample and the evolved $\mathrm{H}_{2} \mathrm{~S}$ was trapped as $\mathrm{Zn}^{35} \mathrm{~S}$ in $5 \mathrm{~mL}$ of $5 \%$ zinc acetate solution. Scintillation counting was used to analyze the radioactivity in the sulfate and TRIS pools and sulfate reduction rates were calculated according to Jørgensen ${ }^{92}$. To determine the water amount and porosity of the sediment, required for calculation of SRR, the weight loss of a known volume of sediment after drying to constant weight at $105^{\circ} \mathrm{C}$ was determined. Some of the SRR data is already published in a recently accepted manuscript ${ }^{98}$. For which stations this is the case is stated in Table S8.

TOC and TN analysis: For TOC and TN measurements, sediment was dried at $105^{\circ} \mathrm{C}$ and powdered using a planetary micro mill (Pulverisette 23, Fritsch). After acidification with $\mathrm{HCl}$ to remove inorganic carbon and washing steps with $\mathrm{MQ}$ water to remove additional salt from the $\mathrm{HCl}$, the powdered sediment was dried again and the carbon and nitrogen amount and isotopic composition was measured with an elemental analyzer (Thermo Fisher Scientific Flash EA 1112) coupled to an IRMS.

Sequential endpoint Fe extractions. Sequential endpoint extractions with $\mathrm{HCl}$, to separate the poorly crystalline $\left(0.5 \mathrm{M} \mathrm{HCl}, 1 \mathrm{~h}, 20^{\circ} \mathrm{C}\right)$ from the crystalline $\left(6 \mathrm{M} \mathrm{HCl}, 24 \mathrm{~h}, 70^{\circ} \mathrm{C}\right) \mathrm{Fe}(\mathrm{II})$ and $\mathrm{Fe}(\mathrm{III})$ in the sediments and the glacial source samples, were done as described by Laufer et al. ${ }^{26}$. Fe(II) and total Fe concentrations in the extracts were determined spectrophotometrically by the ferrozine assay ${ }^{87}$. For total Fe concentrations all $\mathrm{Fe}(\mathrm{III})$ was reduced to $\mathrm{Fe}(\mathrm{II})$ with the reductant hydroxylamine hydrochloride $(\mathrm{HAHCl}, 10 \% \mathrm{w} / \mathrm{v}$ in $1 \mathrm{M} \mathrm{HCl})$ before the assay. Fe(III) was calculated from the difference between Fe(II) and total Fe concentrations. Some of the sequential extractiondata is already published in a recently accepted manuscript ${ }^{26}$ : for which stations this is the case is stated in Table S8. 
428 Ascorbate Fe reduction time-course extractions. Abiotic ascorbate Fe reduction (AFeR) time-course 429 extractions ${ }^{94,95}$ were performed and the dissolution curves of $\mathrm{Fe}(\mathrm{II})$ were used to fit the reactive continuum 430 model and calculate the parameters $\mathrm{M}_{(0)}$ (amount of extractable iron), v/a (apparent rate constant), 1+1/v 431 (heterogeneity parameter) and initial rates as described in detail by Laufer et al. ${ }^{26}$. Statistical tests on the 432 significance of the increase in $\mathrm{M}_{(0)}$ and initial rates in the surface sediment with increasing distance from the 433 glacial source were performed by linear regression analysis in R. Some of the AFeR extraction data is already 434 published in a recently accepted manuscript ${ }^{26}$. For which stations this is the case is stated in Table S8.

435 Microbial Fe reduction time-course extractions. Microbial Fe reduction (MFeR) time-course extractions 436 were performed with a culture of Shewanella frigidimarina DSM-12253 ${ }^{96}$. The dissolution curves of Fe(II) were to determine $\mathrm{M}_{(0)}, \mathrm{v} / \mathrm{a}, 1+1 / \mathrm{v}$ and initial rates the same way as done for ascorbate reduction time-course extractions. Some of the data for MFeR extractions are already published in a recently accepted manuscript ${ }^{26}$ for which stations this is the case is stated in Table S8.

Particle size analysis. Particle size analysis was performed at Binghamton University's Analytical and Diagnostics Laboratory. Approximately $1 \mathrm{~g}$ of bulk sample was gently disaggregated and treated for the removal of organic matter with $\sim 20 \mathrm{ml}$ of $27 \%$ hydrogen peroxide $\left(\mathrm{H}_{2} \mathrm{O}_{2}\right)$ in hot water bath. Smear slides of treated samples were analyzed under a binocular microscope in order to assess for the presence of biogenic components. Given the lack of biogenic material, samples were then treated with $10 \%$ sodium hexametaphosphate and shaken for 12 hours prior to analysis on the Beckman Coulter LS 13320 Laser Diffraction Analyzer.

${ }^{57}$ Fe Mössbauer spectroscopy. Mössbauer spectroscopy analysis was performed at the Center for Applied Geosciences at the University of Tübingen. Freeze-dried samples were loaded into Plexiglas holders (area 1 $\left.\mathrm{cm}^{2}\right)$, forming a thin disc, within an anoxic glovebox $\left(100 \% \mathrm{~N}_{2}\right)$. Sample holders were transported to the instrument within airtight bottles which were only opened immediately prior to loading into a closed-cycle exchange gas cryostat (Janis cryogenics) under a backflow of He to minimize exposure to ambient air. Spectra were collected at 77 and $5 \mathrm{~K}$ using a constant acceleration drive system (WissEL) in transmission mode with a ${ }^{57} \mathrm{Co} / \mathrm{Rh}$ source. All spectra were calibrated against a $7 \mu \mathrm{m}$ thick $\alpha-{ }^{57} \mathrm{Fe}$ foil that was measured at room temperature. Analysis was carried out using Recoil (University of Ottawa) and the Voigt Based Fitting (VBF) routine ${ }^{97}$. The half width at half maximum (HWHM) was constrained to $0.138 \mathrm{~mm} \mathrm{~s}^{-1}$ during fitting. 


\section{Acknowledgements:}

458 We thank the Alfred Wegener Institute-Institute Paul Emile Victor (AWIPEV) station as well as the Josef

459 Svoboda Station of the University of South Bohemia and staff for housing and excellent logistics support. We 460 furthermore thank MS Farm captain Stig Henningsen and first mate, Reidar Sørensen, as well as MS Teisten 461 captain Roar Strand. We appreciate the technical assistance of Karina Bomholt Oest at Aarhus University. This work was supported by the Danish National Research Foundation [DNRF104]; European Research Council [ERC Advanced Grant \#294200 to BBJ]; Danish Council for Independent Research [DFF - 7014-00196 to BBJ]; as well as by postdoctoral fellowships from the US-National Science Foundation [EARPF1625158 to ABM], and the German Research Foundation [DFG389371177 to KL]. The Polar Geospatial Center and Brad Herried provided geospatial support under NSF OPP awards 1043681 and 1559691 and produced maps from ESA remote sensing data. Grain size analysis was supported through funding by Binghamton Universities Analytical and Diagnostics Laboratory (ADL) Small Grant program to MOP. We thank all the participants of the 2017 and 2018 Svalbard KOP 56/RiS 10528 expeditions for help with sample collection and providing stimulating discussions.

\section{Competing interests}

471 The authors declare no conflict of interests.

\section{Data availability}

473 The authors declare that all the data supporting the findings of this study are available in the article and its 474 Supplementary Information files. Any further information is available from the corresponding author upon 475 request.

\section{References}

477 1. Tagliabue, A. et al. The integral role of iron in ocean biogeochemistry. Nature 543, 51-59 (2017).

2. Boyd, P. W. et al. Mesoscale iron enrichment experiments 1993-2005: Synthesis and future directions. Science. 315, 612-617 (2007).

3. Klunder, M. B. et al. Dissolved iron in the Arctic shelf seas and surface waters of the central Arctic Ocean: Impact of Arctic river water and ice-melt. J. Geophys. Res. Ocean. 117, 1-18 (2012). Fe in the deep and upper Arctic Ocean with a focus on Fe limitation in the Nansen Basin. Front. Mar. Sci. 
5, 88 (2018).

485

486

487

488

489

490

491

492

493

494

495

496

497

498

499

500

501

502

503

504

505

506

507

508

5. Arrigo, K. R. et al. Melting glaciers stimulate large summer phytoplankton blooms in southwest Greenland waters. Geophys. Res. Lett. 44, 6278-6285 (2017).

6. Drever, J. I. The geochemistry of natural waters: surface and groundwater environments. J. Environ. Qual. 27, 245-245 (1998).

7. Ryan-Keogh, T. J. et al. Spatial and temporal development of phytoplankton iron stress in relation to bloom dynamics in the high-latitude North Atlantic Ocean. Limnol. Oceanogr. 58, 533-545 (2013).

8. Dethloff, K., Handorf, D., Jaiser, R., Rinke, A. \& Klinghammer, P. Dynamical mechanisms of Arctic amplification. Ann. N. Y. Acad. Sci. 1436, 184-194 (2019).

9. Serreze, M. C. \& Barry, R. G. Processes and impacts of Arctic amplification: A research synthesis. Glob. Planet. Change 77, 85-96 (2011).

10. Bianchi, T. S. et al. Fjords as Aquatic Critical Zones (ACZs). Earth-Science Rev. 203, 103145 (2020).

11. Smith, R. W., Bianchi, T. S., Allison, M., Savage, C. \& Galy, V. High rates of organic carbon burial in fjord sediments globally. Nat. Geosci. 8, 450-453 (2015).

12. Wadham, J. L. et al. The potential role of the Antarctic Ice Sheet in global biogeochemical cycles. Earth Environ. Sci. Trans. R. Soc. Edinburgh 104, 55-67 (2013).

13. Raiswell, R. et al. Contributions from glacially derived sediment to the global iron (oxyhydr) oxide cycle: implications for iron delivery to the oceans. Geochim. Cosmochim. Acta 70, 2765-2780 (2006).

14. Raiswell, R. \& Canfield, D. E. The iron biogeochemical cycle past and present. Geochemical Perspect. 1, $1-2(2012)$.

15. Bhatia, M. P. et al. Greenland meltwater as a significant and potentially bioavailable source of iron to the ocean. Nat. Geosci. 6, 274-278 (2013).

16. Raiswell, R. Biogeochemistry: Rusty meltwaters. Nat. Geosci. 6, 251-252 (2013).

17. Schroth, A. W., Crusius, J., Hoyer, I. \& Campbell, R. Estuarine removal of glacial iron and implications for iron fluxes to the ocean. Geophys. Res. Lett. 21, 3494-3501 (2014). 
18. Raiswell, R. et al. Iron in Glacial Systems: Speciation, Reactivity, Freezing Behaviour and Alteration during Transport. Front. Earth Sci. 6, 222 (2018).

19. Zhang, R. et al. Transport and reaction of iron and iron stable isotopes in glacial meltwaters on Svalbard near Kongsfjorden: From rivers to estuary to ocean. Earth Planet. Sci. Lett. 424, 201-211 (2015).

20. Meslard, F., Bourrin, F., Many, G. \& Kerhervé, P. Suspended particle dynamics and fluxes in an Arctic fjord (Kongsfjorden, Svalbard). Estuar. Coast. Shelf Sci. 204, 212-224 (2018).

21. Li, X. et al. Dissolved Iron Supply from Asian Glaciers: Local Controls and a Regional Perspective. Global Biogeochem. Cycles 33, 1223-1237 (2019).

22. Raiswell, R., Vu, H. P., Brinza, L. \& Benning, L. G. The determination of labile Fe in ferrihydrite by ascorbic acid extraction: Methodology, dissolution kinetics and loss of solubility with age and dewatering. Chem. Geol. 278, 70-79 (2010).

23. Raiswell, R. et al. Potentially bioavailable iron delivery by iceberg-hosted sediments and atmospheric dust to the polar oceans. Biogeosciences 13, 3887-3900 (2016).

24. Yoshida, M. et al. Effect of aging time on the availability of freshly precipitated ferric hydroxide to coastal marine diatoms. Mar. Biol. 149, 379-392 (2006).

25. Postma, D. \& Jakobsen, R. Redox zonation: equilibrium constraints on the Fe (III)/SO 4-reduction interface. Geochim. Cosmochim. Acta 60, 3169-3175 (1996).

26. Laufer, K., Michaud, A., Røy, H. \& Jørgensen, B. Reactivity of iron minerals in the seabed towards microbial reduction - a comparison of different extraction techniques. Geomicrobiol. J. 37, 170-189 (2020).

27. Raiswell, R., Benning, L. G., Tranter, M. \& Tulaczyk, S. Bioavailable iron in the Southern Ocean: the significance of the iceberg conveyor belt. Geochem. Trans. 9, 7 (2008).

28. Hopwood, M. J. \& Cantoni, C. The heterogeneous nature of Fe delivery from melting icebergs. Geochem. Perspect. Lett. 3, 200-209 (2017).

29. Hawkings, J. R. et al. Ice sheets as a significant source of highly reactive nanoparticulate iron to the oceans. Nat. Commun. 5, 1-8 (2014). 
30. Michaud, A. B. et al. Glacial influence on the iron and sulfur cycles in Arctic fjord sediments (Svalbard). Geochim. Cosmochim. Acta 280, 423-440 (2020).

31. Melton, E. D., Swanner, E. D., Behrens, S., Schmidt, C. \& Kappler, A. The interplay of microbially mediated and abiotic reactions in the biogeochemical Fe cycle. Nat Rev Micro 12, 797-808 (2014).

32. Coby, A. J., Picardal, F., Shelobolina, E., Xu, H. \& Roden, E. E. Repeated anaerobic microbial redox cycling of iron. Appl Env. Microbiol 77, 6036-6042 (2011).

33. Mejia, J., Roden, E. E. \& Ginder-Vogel, M. Influence of Oxygen and Nitrate on Fe (Hydr)oxide Mineral Transformation and Soil Microbial Communities during Redox Cycling. Environ. Sci. Technol. 50, 35803588 (2016).

34. Bonneville, S., Van Cappellen, P. \& Behrends, T. Microbial reduction of iron (III) oxyhydroxides: effects of mineral solubility and availability. Chem. Geol. 212, 255-268 (2004).

35. Komlos, J., Kukkadapu, R. K., Zachara, J. M. \& Jaffé, P. R. Biostimulation of iron reduction and subsequent oxidation of sediment containing Fe-silicates and Fe-oxides: Effect of redox cycling on Fe(III) bioreduction. Water Res. 41, 2996-3004 (2007).

36. Dong, H., Jaisi, D. P., Kim, J. \& Zhang, G. Microbe-clay mineral interactions. Am. Mineral. 94, 1505-1519 (2009).

37. Emerson, D. Biogenic iron dust: a novel approach to ocean iron fertilization as a means of large scale removal of carbon dioxide from the atmosphere. Front. Mar. Sci. 6, 22 (2019).

38. Chan, C. S., Fakra, S. C., Edwards, D. C., Emerson, D. \& Banfield, J. F. Iron oxyhydroxide mineralization on microbial extracellular polysaccharides. Geochim. Cosmochim. Acta 73, 3807-3818 (2009).

39. Shi, F. et al. Clay minerals in Arctic Kongsfjorden surface sediments and their implications on provenance and paleoenvironmental change. Acta Oceanol. Sin. 37, 29-38 (2018).

40. Shoenfelt, E. M. et al. High particulate iron(II) content in glacially sourced dusts enhances productivity of a model diatom. Sci. Adv. 3, e1700314 (2017).

41. Shelobolina, E. S., VanPraagh, C. G. \& Lovley, D. R. Use of ferric and ferrous iron containing minerals for respiration by Desulfitobacterium frappieri. Geomicrobiol. J. 20, 143-156 (2003). 
561 42. Zhao, L., Dong, H., Edelmann, R. E., Zeng, Q. \& Agrawal, A. Coupling of Fe(II) oxidation in illite with nitrate reduction and its role in clay mineral transformation. Geochim. Cosmochim. Acta 200, 353-366

564

565

566

567

568

569

570

571

572

573

574

575

576

577

578

579

580

581

582

583

584 585

586 (2017).

43. Milner, A. M. et al. Glacier shrinkage driving global changes in downstream systems. Proc. Natl. Acad. Sci. 114, 9770-9778 (2017).

44. Hopwood, M. J. et al. Non-linear response of summertime marine productivity to increased meltwater discharge around Greenland. Nat. Commun. 9, 1-9 (2018).

45. Halbach, L. et al. Tidewater Glaciers and Bedrock Characteristics Control the Phytoplankton Growth Environment in a Fjord in the Arctic. Frontiers in Marine Science 6, 1-18 (2019).

46. Meire, L. et al. Marine-terminating glaciers sustain high productivity in Greenland fjords. Glob. Chang. Biol. 23, 5344-5357 (2017).

47. Hopwood, M. et al. How does glacier discharge affect marine biogeochemistry and primary production in the Arctic? Cryosph. Discuss. 14, 1347-1383 (2019).

48. Wehrmann, L. M. et al. Iron and manganese speciation and cycling in glacially influenced high-latitude fjord sediments (West Spitsbergen, Svalbard): Evidence for a benthic recycling-transport mechanism. Geochim. Cosmochim. Acta 141, 628-655 (2014).

49. Wehrmann, L. M. et al. Iron-controlled oxidative sulfur cycling recorded in the distribution and isotopic composition of sulfur species in glacially influenced fjord sediments of west Svalbard. Chem. Geol. 466, 678-695 (2017).

50. Shaw, T. J. et al. Input, composition, and potential impact of terrigenous material from free-drifting icebergs in the Weddell Sea. Deep Sea Res. Part II Top. Stud. Oceanogr. 58, 1376-1383 (2011).

51. Hopwood, M. J., Statham, P. J., Tranter, M. \& Wadham, J. L. Glacial flours as a potential source of Fe(II) and Fe(III) to polar waters. Biogeochemistry 118, 443-452 (2014).

52. Li, X. et al. Dissolved iron supply from Asian glaciers: local controls and a regional perspective. Global Biogeochem. Cycles 33, 1223-1237 (2019).

53. Macdonald, M. L., Wadham, J. L., Telling, J. \& Skidmore, M. L. Glacial erosion liberates lithologic energy 
600

601

602

603

604

605

606

607

608

609

610

611

612

sources for microbes and acidity for chemical weathering beneath glaciers and ice sheets. Front. Earth Sci. 6, 1-15 (2018).

54. Hopwood, M. J., Cantoni, C., Clarke, J. S., Cozzi, S. \& Achterberg, E. P. The heterogeneous nature of Fe delivery from melting icebergs. Geochemical Perspect. Lett. 3 200-209 (2017).

55. Hatton, J. E. et al. Investigation of subglacial weathering under the Greenland Ice Sheet using silicon isotopes. Geochim. Cosmochim. Acta 247, 191-206 (2019).

56. Dallmann, W. K. Geoscience Atlas of Svalbard. (Norsk polarinstitutt, Troms $\varnothing 2015$ ).

57. Kvam, M. H. Deposits and processes on the tide-influenced fjord- head delta in Dicksonfjorden , Svalbard. Masters Thesis UiT Norges Arktiske Universitet (2018).

58. Herbert, L. C. et al. Glacial controls on redox-sensitive trace element cycling in Arctic fjord sediments (Spitsbergen, Svalbard). Geochim. Cosmochim. Acta 271, 33-60 (2020).

59. Bennett, P. C., Rogers, J. R., Choi, W. J. \& Hiebert, F. K. Silicates, silicate weathering, and microbial ecology. Geomicrobiol. J. 18, 3-19 (2001).

60. Jung, J. et al. Microbial Fe (III) reduction as a potential iron source from Holocene sediments beneath Larsen Ice Shelf. Nat. Commun. 10, 1-10 (2019).

61. Koziorowska, K., Kuliński, K. \& Pempkowiak, J. Distribution and origin of inorganic and organic carbon in the sediments of Kongsfjorden, Northwest Spitsbergen, European Arctic. Cont. Shelf Res. 150, 27-35 (2017).

62. Svendsen, H. et al. The physical environment of Kongsfjorden - Krossfjorden, an Arctic fjord system in Svalbard. Polar Res. 21, 133-166 (2002).

63. Kotwicki, L., Szymelfenig, M., De Troch, M. \& Zajaczkowski, M. Distribution of meiofauna in Kongsfjorden, Spitsbergen. Polar Biol. 27, 661-669 (2004).

64. Hop, H. et al. The marine ecosystem of Kongsfjorden, Svalbard. Polar Res. 21, 167-208 (2002).

65. Kim, J. H. et al. Large ancient organic matter contributions to Arctic marine sediments (Svalbard). Limnol. Oceanogr. 56, 1463-1474 (2011).

66. Piwosz, K. et al. Comparison of productivity and phytoplankton in a warm (Kongsfjorden) and a cold 
(Hornsund) Spitsbergen fjord in mid-summer 2002. Polar Biol. 32, 549-559 (2009).

614

615

616

617

618

619

620

621

622

623

624

625

626

627

628

629

630

631

632

633

634

635

636

637

638

67. Meyers, P. A. \& Ishiwatari, R. Lacustrine organic geochemistry-an overview of indicators of organic matter sources and diagenesis in lake sediments. Org. Geochem. 20, 867-900 (1993).

68. Lee, Y. II, Lim, H. S. \& Yoon, H. II. Carbon and nitrogen isotope composition of vegetation on King George Island, maritime Antarctic. Polar Biol. 32, 1607-1615 (2009).

69. Müller, P. J. CN ratios in Pacific deep-sea sediments: Effect of inorganic ammonium and organic nitrogen compounds sorbed by clays. Geochim. Cosmochim. Acta 41, 765-776 (1977).

70. Koziorowska, K., Kuliński, K. \& Pempkowiak, J. Comparison of the burial rate estimation methods of organic and inorganic carbon and quantification of carbon burial in two high Arctic fjords. Oceanologia 60, 405-418 (2018).

71. Koziorowska, K., Kuliński, K. \& Pempkowiak, J. Sedimentary organic matter in two Spitsbergen fjords: Terrestrial and marine contributions based on carbon and nitrogen contents and stable isotopes composition. Cont. Shelf Res. 113, 38-46 (2016).

72. Buongiorno, J. et al. Complex microbial communities drive iron and sulfur cycling in Arctic fjord sediments. Appl. Environ. Microbiol. 85, e00949-19 (2019).

73. Pelikan, C. et al. Glacial runoff promotes deep burial of sulfur cycling-associated microorganisms in marine sediments. bioRxiv 661207 (2019).

74. Hooke, R. L. \& Elverhøi, A. Sediment flux from a fjord during glacial periods, Isfjorden, Spitsbergen. Glob. Planet. Change 12, 237-249 (1996).

75. Elverhøi, A., Liestøl, O. \& Nagy, J. Glacial erosion, sedimentation and microfauna in the inner part of Kongsfjorden, Spitsbergen. (Norsk Polarinstitutt Skrifter, Troms $\varnothing, 1980)$.

76. Wlodarska-Kowalczuk, M. \& Pearson, T. H. Soft-bottom macrobenthic faunal associations and factors affecting species distributions in an Arctic glacial fjord (Kongsfjord, Spitsbergen). Polar Biol. 27, 155-167 (2004).

77. Beam, J. P. et al. Biological rejuvenation of iron oxides in bioturbated marine sediments. ISME J. 5, 13891394 (2018). 
639

640

641

642

643

644

645

646

647

648

649

650

651

652

653

654

655

656

657

658

659

660

661

662

663

664

78. van de Velde, S. \& Meysman, F. J. R. The Influence of Bioturbation on Iron and Sulphur Cycling in Marine Sediments: A Model Analysis. Aquat. Geochemistry 22, 469-504 (2016).

79. Zajączkowski, M. Sediment supply and fluxes in glacial and outwash fjords, Kongsfjorden and Adventfjorden, Svalbard. Pol. Polar Res 29, 59-72 (2008).

80. Raiswell, R. Iron transport from the continents to the open ocean: The aging-rejuvenation cycle. Elements 7, 101-106 (2011).

81. Burdige, D. J. \& Komada, T. Iron redox cycling, sediment resuspension and the role of sediments in low oxygen environments as sources of iron to the water column. Mar. Chem. 223, 103793 (2020).

82. Schlosser, C. et al. Mechanisms of dissolved and labile particulate iron supply to shelf waters and phytoplankton blooms off South Georgia, Southern Ocean. Biogeosciences 15, 4973-4993 (2018).

83. Lam, P., Heller, M. I., Lerner, P. E., Moffett, J. W. \& Buck, K. Unexpected source and transport of iron from the deep Peru Margin. ACS Earth Sp. Chem. 4, 977-992 (2020).

84. Klar, J. K. et al. Stability of dissolved and soluble Fe(II) in shelf sediment pore waters and release to an oxic water column. Biogeochemistry 135, 49-67 (2017).

85. Kanneworff, E. \& Nicolaisen, W. The " Haps" a frame-supported bottom corer. Ophelia 10, 119-129 (1973).

86. Keimowitz, A. R., Zheng, Y., Lee, M.-K., Natter, M. \& Keevan, J. Sediment Core Sectioning and Extraction of Pore Waters under Anoxic Conditions. JoVE 109, e53393-e53393 (2016).

87. Stookey, L. L. Ferrozine - a New Spectrophotometric Reagent for Iron. Anal. Chem. 42, 779-781 (1970).

88. Goto, K., Komatsu, T. \& Furukawa, T. Rapid colorimetric determination of manganese in waters containing iron. A modification of the formaldoxime method. Anal. Chim. Acta 27, 335-338 (1962).

89. Brewer, P. G. \& Spencer, D. W. Colorimetric Determination of Manganese in Anoxic Waters. Limnol. Oceanogr. 16, 107-110 (1971).

90. Otte, J. M. Iron-cycling microorganisms in marine and freshwater sediments and implications for greenhouse gas emission. (Eberhard Karls Universität, Tübingen 2018).

91. Tebo, B. M., Clement, B. G. \& Dick, G. J. Biotransformations of manganese. in Manual of Environmental 
Microbiology, Third Edition 1223-1238 (American Society of Microbiology, 2007).

$66692 . \quad J \emptyset r g e n s e n$, B. B. A comparison of methods for the quantification of bacterial sulfate reduction in coastal 667 marine sediments. Geomicrobiol. J. 1, 11-27 (1978).

668

93. Røy, H., Weber, H. S., Tarpgaard, I. H., Ferdelman, T. G. \& Jørgensen, B. B. Determination of dissimilatory 669

670 sulfate reduction rates in marine sediment via radioactive $35 \mathrm{~S}$ tracer. Limnol. Oceanogr. Methods 12, 196-211 (2014).

671

94. Postma, D. The reactivity of iron oxides in sediments: a kinetic approach. Geochim. Cosmochim. Acta 57, 672 5027-5034 (1993).

673

95. Hyacinthe, C., Bonneville, S. \& Van Cappellen, P. Reactive iron(III) in sediments: Chemical versus 674 microbial extractions. Geochim. Cosmochim. Acta 70, 4166-4180 (2006).

675

96. Bowman, J. P. et al. Shewanella gelidimarina sp. nov. and Shewanella frigidimarina sp. nov., novel 676 Antarctic species with the ability to produce eicosapentaenoic acid (20:5 omega 3) and grow anaerobically by dissimilatory Fe(III) reduction. Int. J. Syst. Bacteriol. 47, 1040-1047 (1997).

678

97. Rancourt, D. G. \& Ping, J. Y. Voigt-based distributions methods for arbitrary-shape in Mössbauer 679 spectroscopy static hyperfine parameter. Nucl. Instruments Methods Phys. Res. B 58, 85-97 (1991).

680

681 682

98. Jørgensen B.B., Laufer K., Michaud A.B., Wehrmann L.M.. Biogeochemistry and microbiology of high Arctic marine sediment ecosystems - case study Svalbard fjords. Limnol. Oceanogr. (accepted) 


\section{Figures}

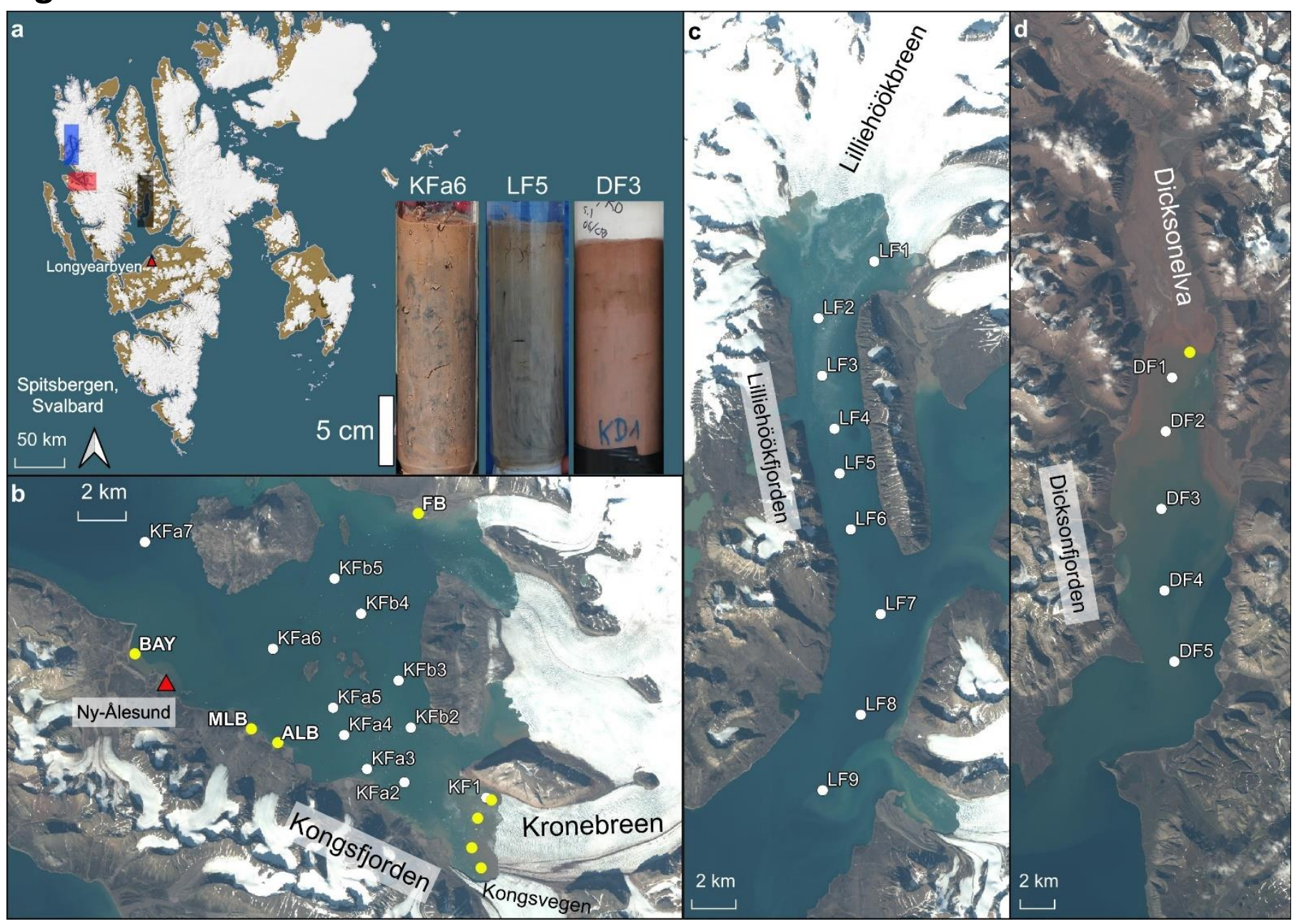

Figure 1: Map of sampling stations. a: Overview map of Svalbard, with the three investigated fjords indicated by colored rectangles, and examples of a sediment core from each fjord (Kongsfjorden= red, core KFa6; Lilliehöökfjorden= blue, core LF5; Dicksonfjorden= grey, core DF3). b-d: Maps of sampling stations in the individual fjords; $\mathbf{b}=$ Kongsfjorden, $\mathbf{c}=$ Lilliehöökfjorden, $\mathbf{d}=$ Dicksonfjorden. White dots represent sediment sampling stations. Yellow dots represent glacial source sampling stations. The yellow dots without labels indicate plume and iceberg samples. 10-m satellite imagery from Sentinel-2 taken on 2 August 2017. 

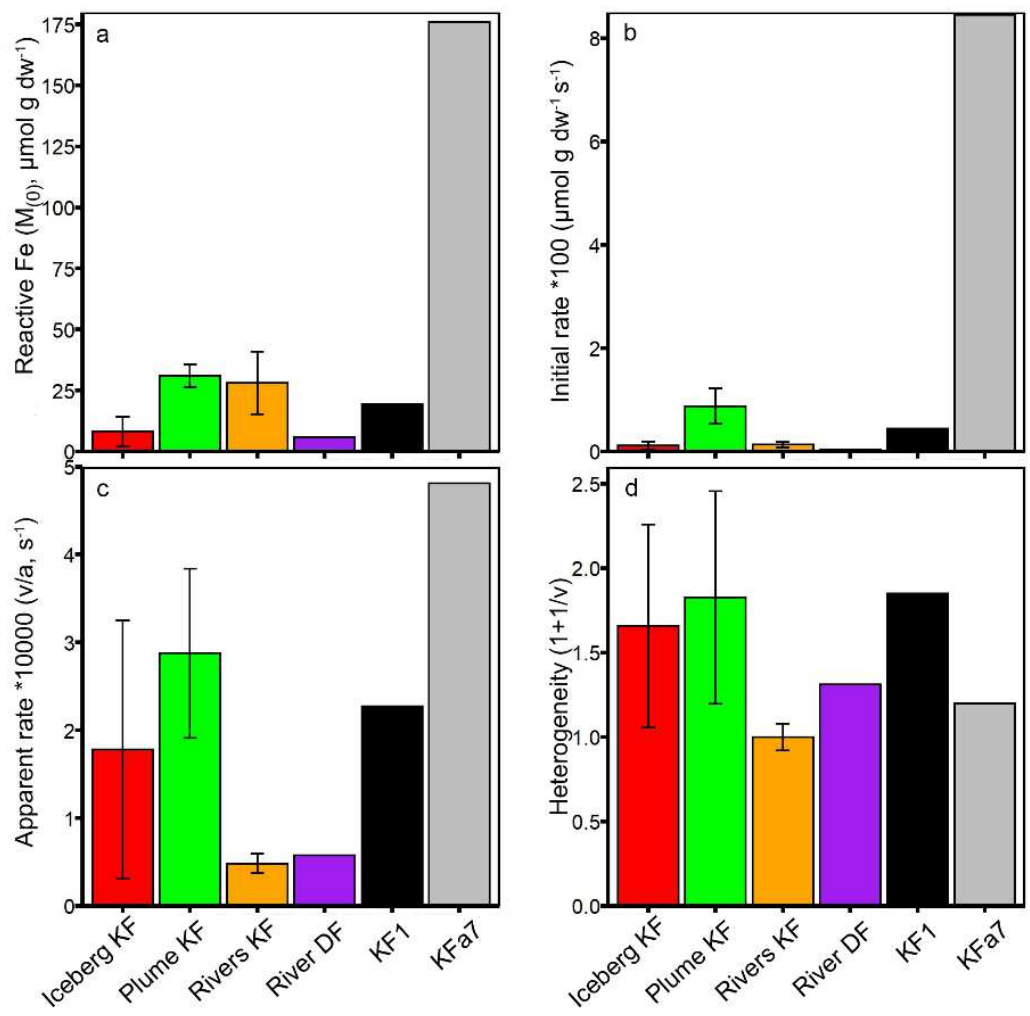

Figure 2: Reactive iron amount and characteristics from AFeR extractions of glacial source material and surface sediment. a: amount of reactive $\mathrm{Fe}, \mathbf{b}$ : initial rate, c: apparent rate constant and $\mathbf{d}$ : heterogeneity. For Iceberg KF, Plume KF and Rivers KF bars represent averages and the error bars show the standard deviation. For River DF, KF1 and KFa7 only one value is available. KF1 and KFa7 are the values from 0-1 cm sediment depth. 

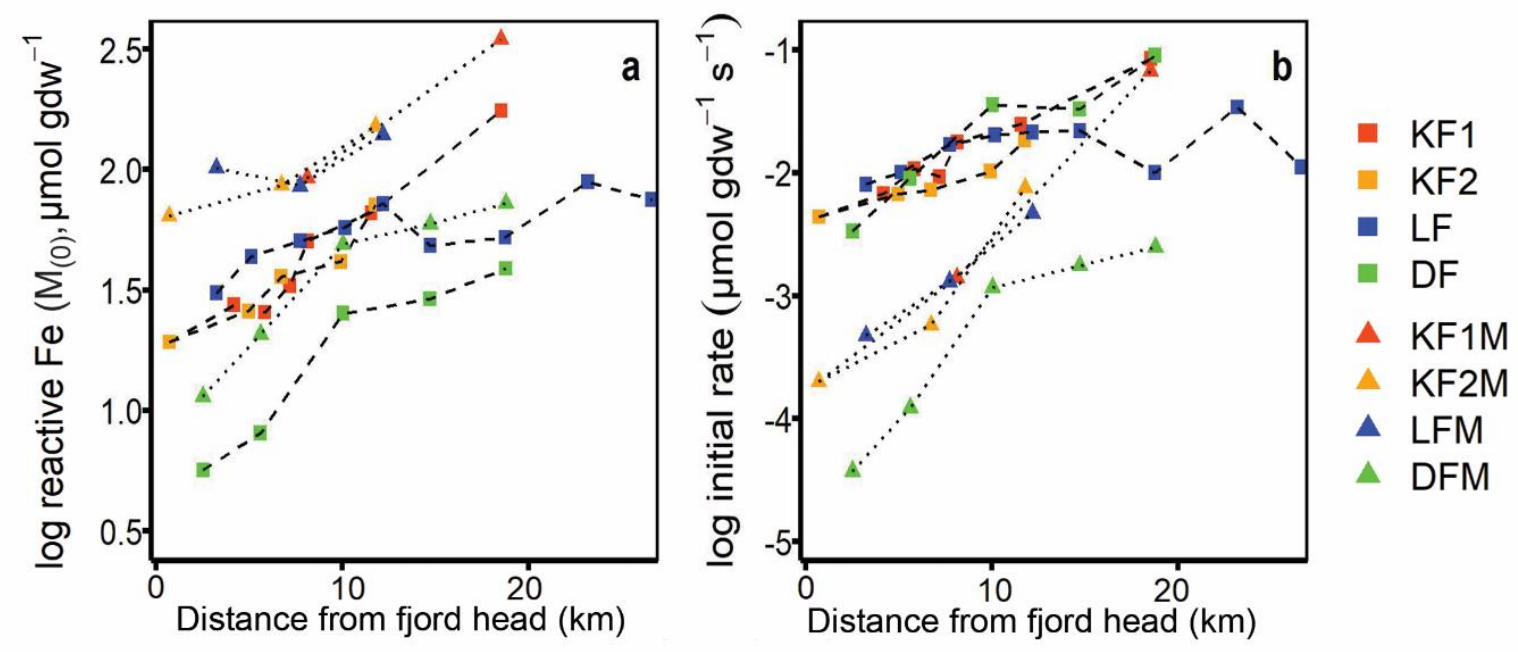

Figure 3: Amount $\left(\mathrm{M}_{(0)}\right)$ and reducibility (initial rate) of FeR versus distance from the fjord head. $a$ and $b$ amount $\left(\mathrm{M}_{(0)}\right)$ and reducibility (initial rate), respectively, of the surface sediment as determined in AFeR (squares) and MFeR (triangles) extractions. 


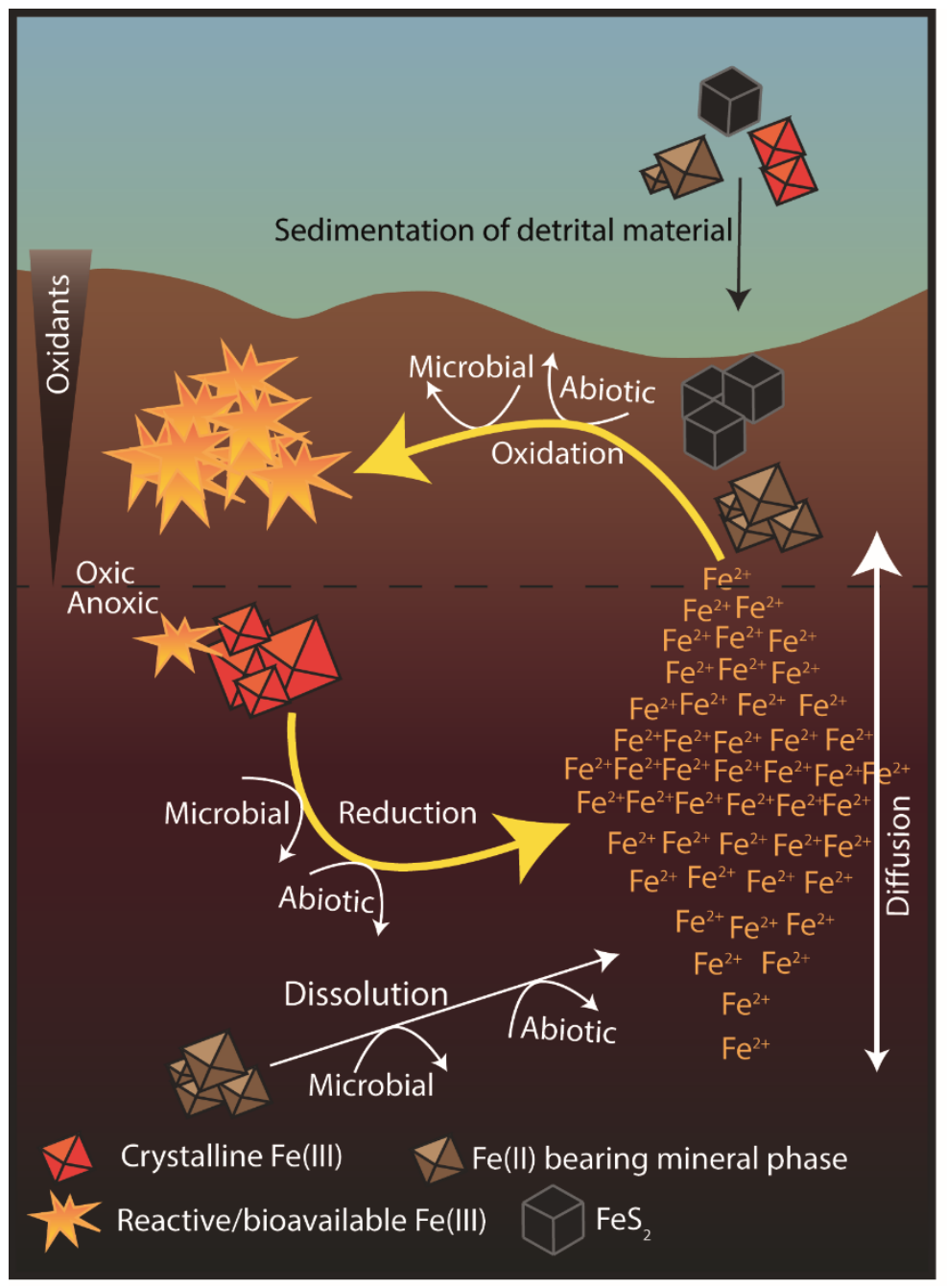

Figure 4: Schematic figure of how benthic iron cycling produces reactive iron at the oxic-anoxic interface in fjord sediments. 

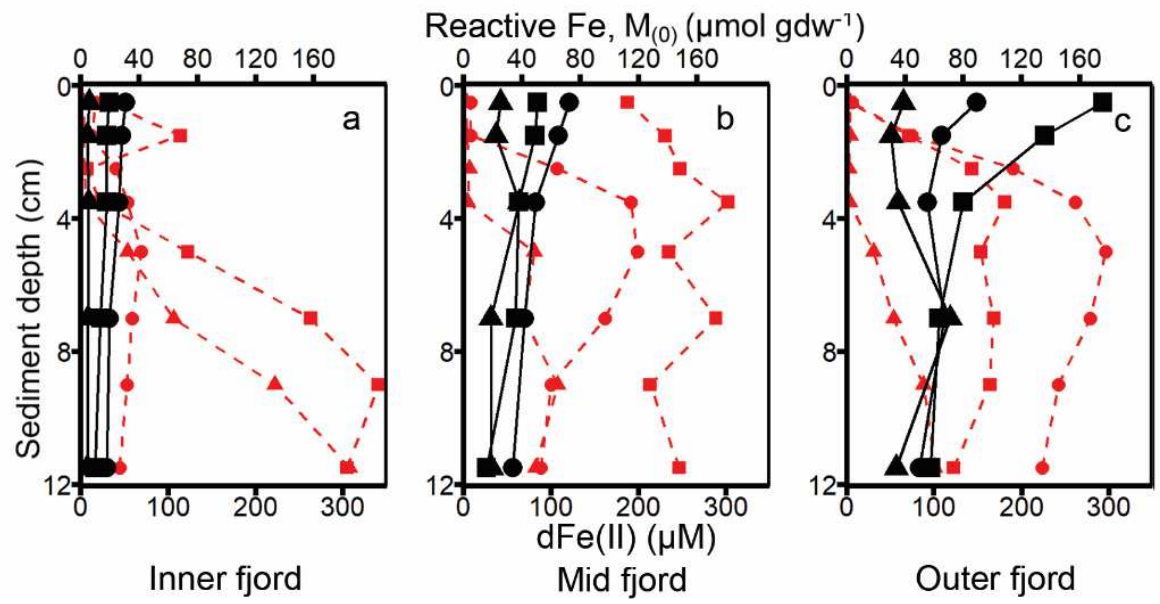

- dFe(II) $\mathrm{KFa}$

- dFe(II) LF

$\Delta$ dFe(II) DF

- $\mathrm{M}_{(0)} \mathrm{KFa}$

- $\mathrm{M}_{(0)} \mathrm{LF}$

$\Delta \mathrm{M}_{(0)} \mathrm{DF}$

Figure 5: Concentrations of reactive iron, and dissolved iron and manganese over sediment depth at three stations within the transects. The three frames show the amount of reactive iron $\left(\mathrm{M}_{(0)}\right.$, determined in $A F e R$ extractions) and concentration of dissolved iron ( $\mathrm{dFe}(\mathrm{II})$ ) in the pore water versus sediment depth at a: stations closest to the fjord head (Kongsfjorden $=$ KFa1, Lilliehöökfjorden = LF1, Dicksonfjorden= DF1); $\mathbf{b}$ : mid-fjord stations (Kongsfjorden $=\mathrm{KFa} 5$, Lilliehöökfjorden = LF5, Dicksonfjorden = DF3); and $\mathrm{c}$ : stations closest to the fjord mouth (Kongsfjorden = KFa7, Lilliehöökfjorden = LF8, Dicksonfjorden = DF5). 
$\mathrm{dFe}(\mathrm{II})$ and $\mathrm{dMn}(\mu \mathrm{M})$
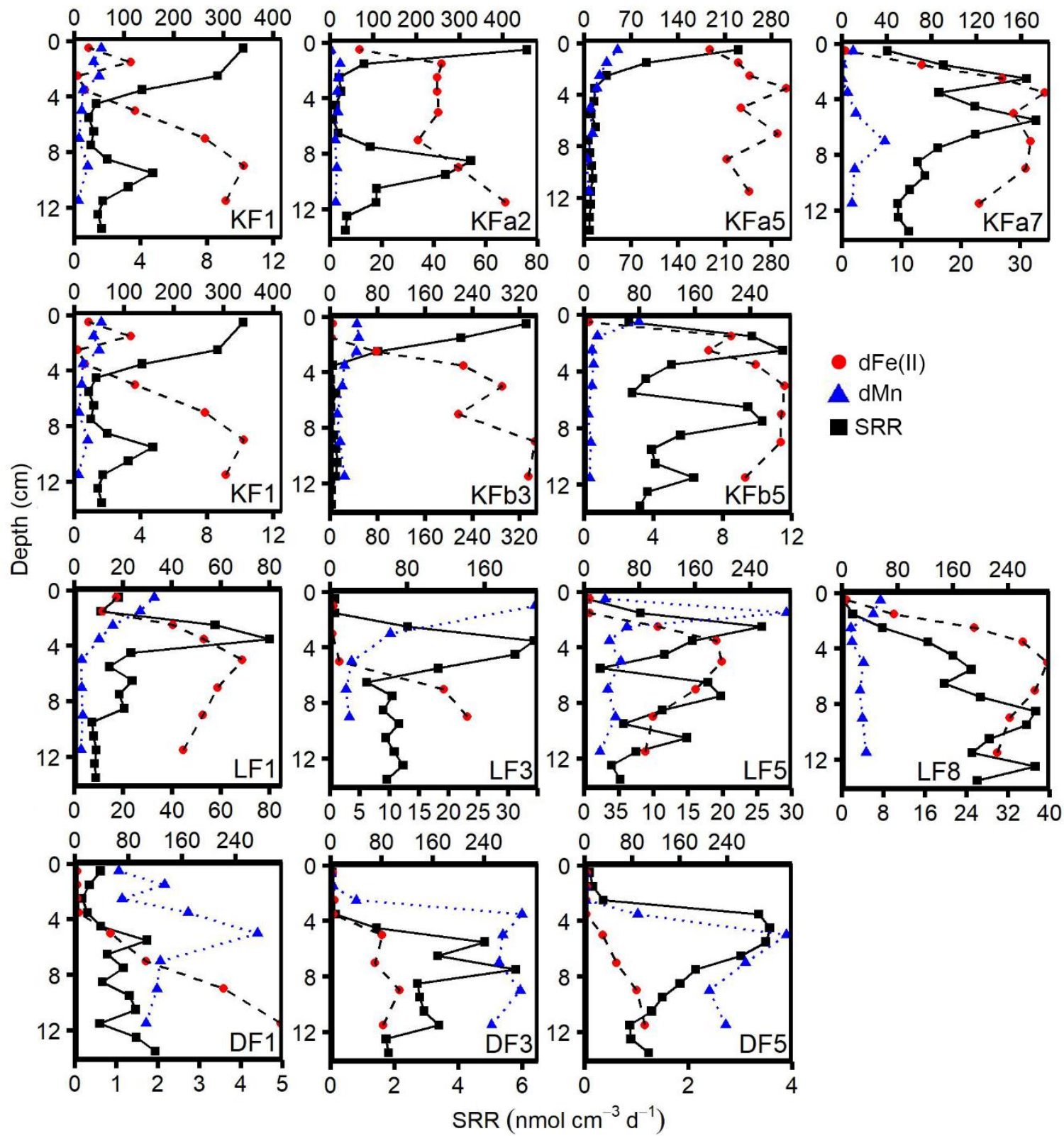

Figure 6: Pore water profiles of $\mathrm{dFe}(\mathrm{II})$ and $\mathrm{dMn}$ and distribution of sulfate reduction rates (SRR) at the main stations in all transects. 

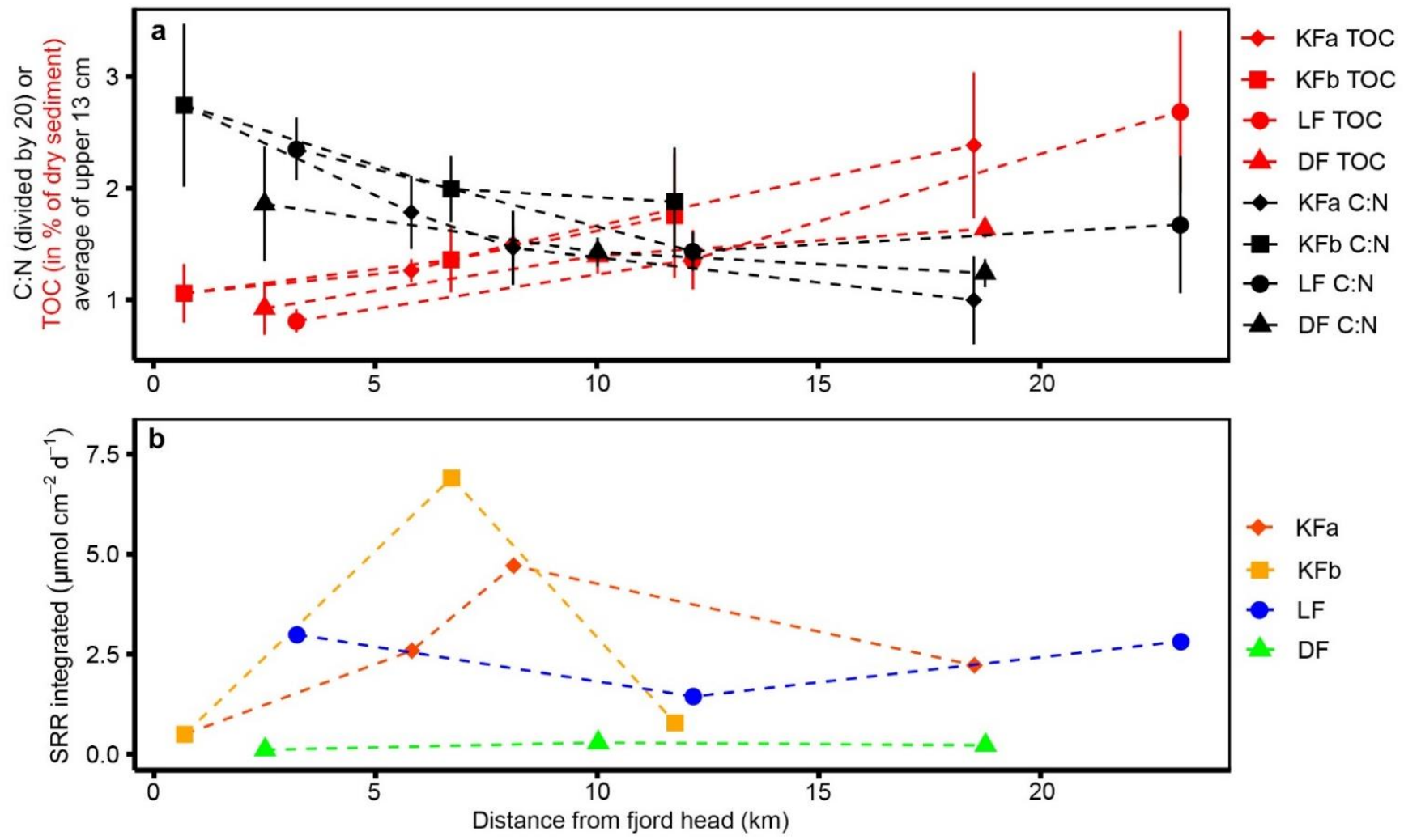

Figure 7: TOC, C:N and integrated SRR over distance from the fjord head. 


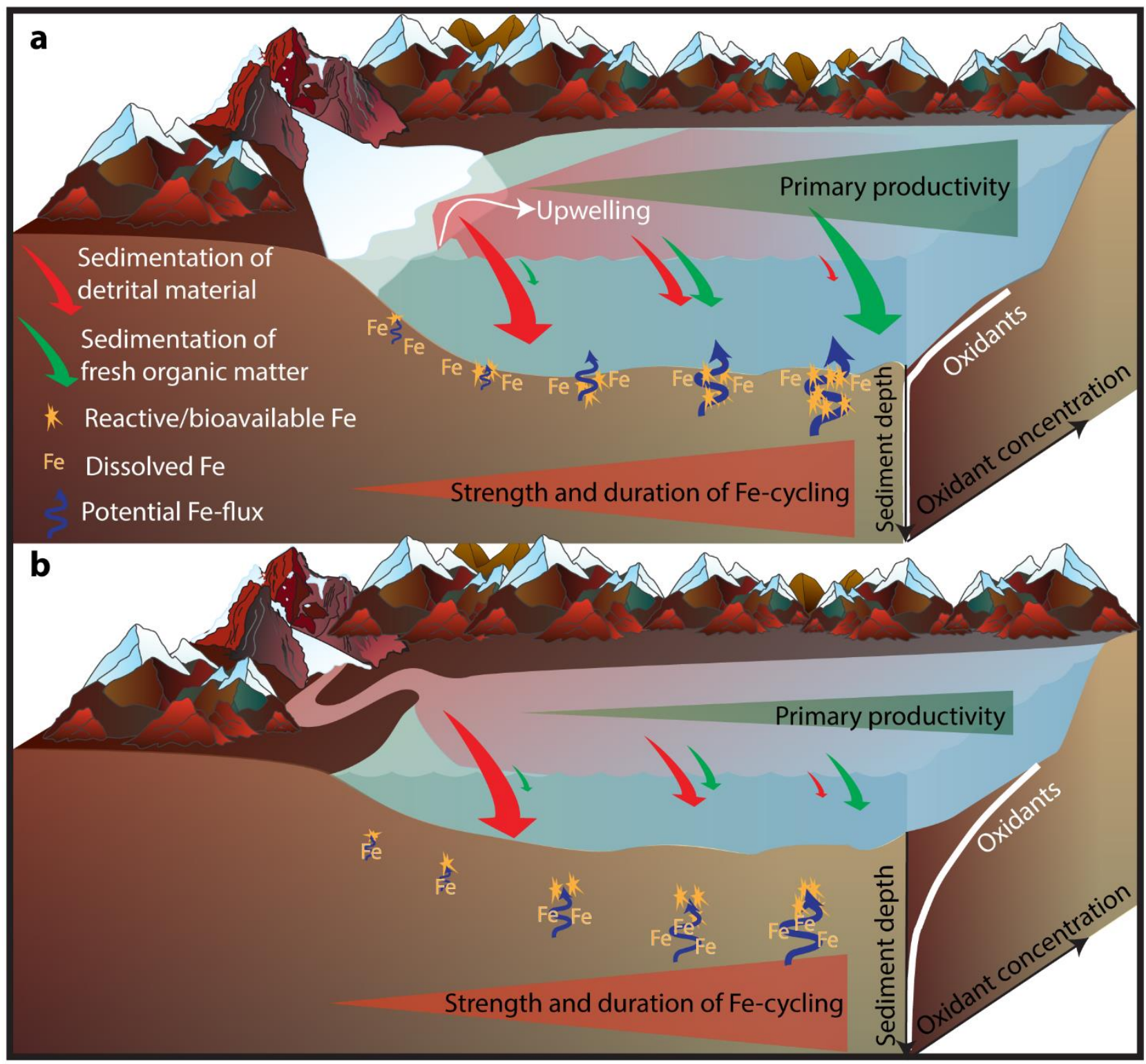

Figure 8: Schematic comparison of current (a, Kongsfjorden) and future (b, Dicksonfjorden) scenarios. The strength of the processes is indicated by symbol/arrow size. a: Fe cycling in a fjord with a marine-terminating glacier and $b$ with a land-terminating glacier. Fe-cycling is impacted by the gradients of input of detrital material and fresh organic matter. Symbol descriptions in panel a also apply to panel $\mathbf{b}$. 


\section{Figures}

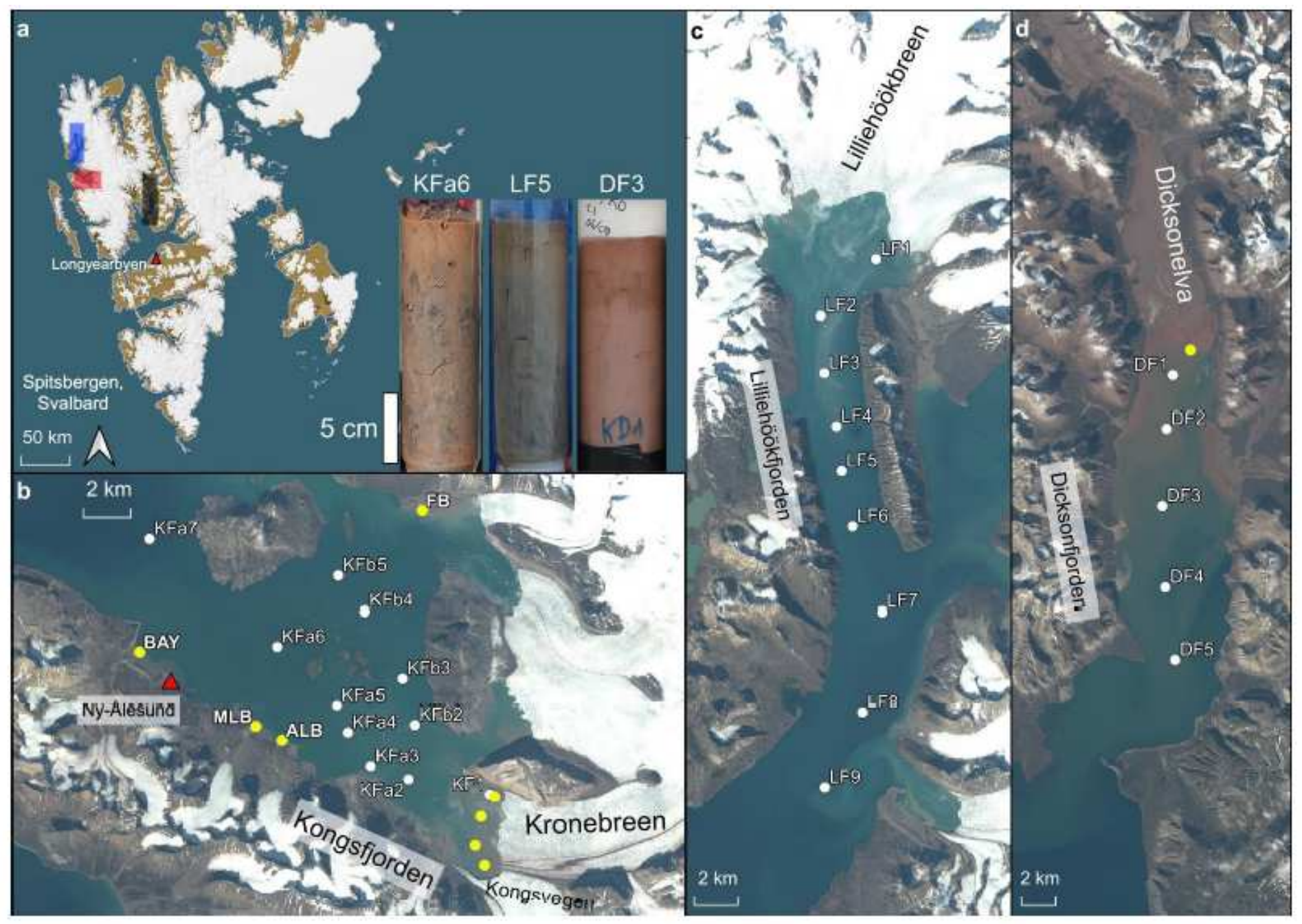

\section{Figure 1}

Map of sampling stations. a: Overview map of Svalbard, with the three investigated fjords indicated by colored rectangles, and examples of a sediment core from each fjord (Kongsfjorden= red, core KFa6; Lilliehöökfjorden= blue, core LF5; Dicksonfjorden= grey, core DF3). b-d: Maps of sampling stations in the individual fjords; $b=$ Kongsfjorden, $c=$ Lilliehöökfjorden, $d=$ Dicksonfjorden. White dots represent sediment sampling stations. Yellow dots represent glacial source sampling stations. The yellow dots without labels indicate plume and iceberg samples. 10-m satellite imagery from Sentinel-2 taken on 2 August 2017. 

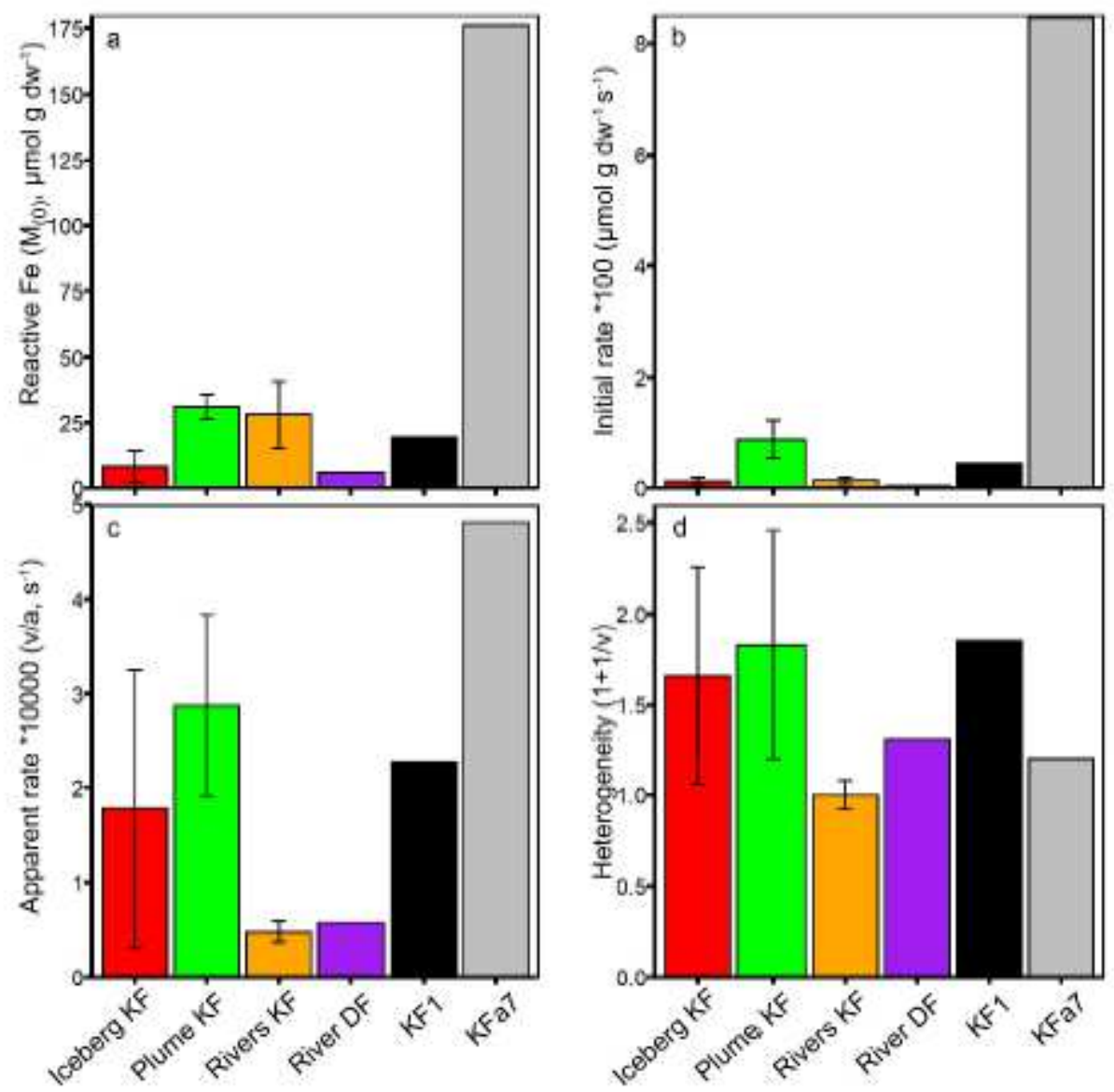

Figure 2

Reactive iron amount and characteristics from AFeR extractions of glacial source material and surface sediment. a: amount of reactive $\mathrm{Fe}$, b: initial rate, c: apparent rate constant and d: heterogeneity. For Iceberg KF, Plume KF and Rivers KF bars represent averages and the error bars show the standard deviation. For River DF, KF1 and KFa7 only one value is available. KF1 and KFa7 are the values from 0-1 cm sediment depth. 

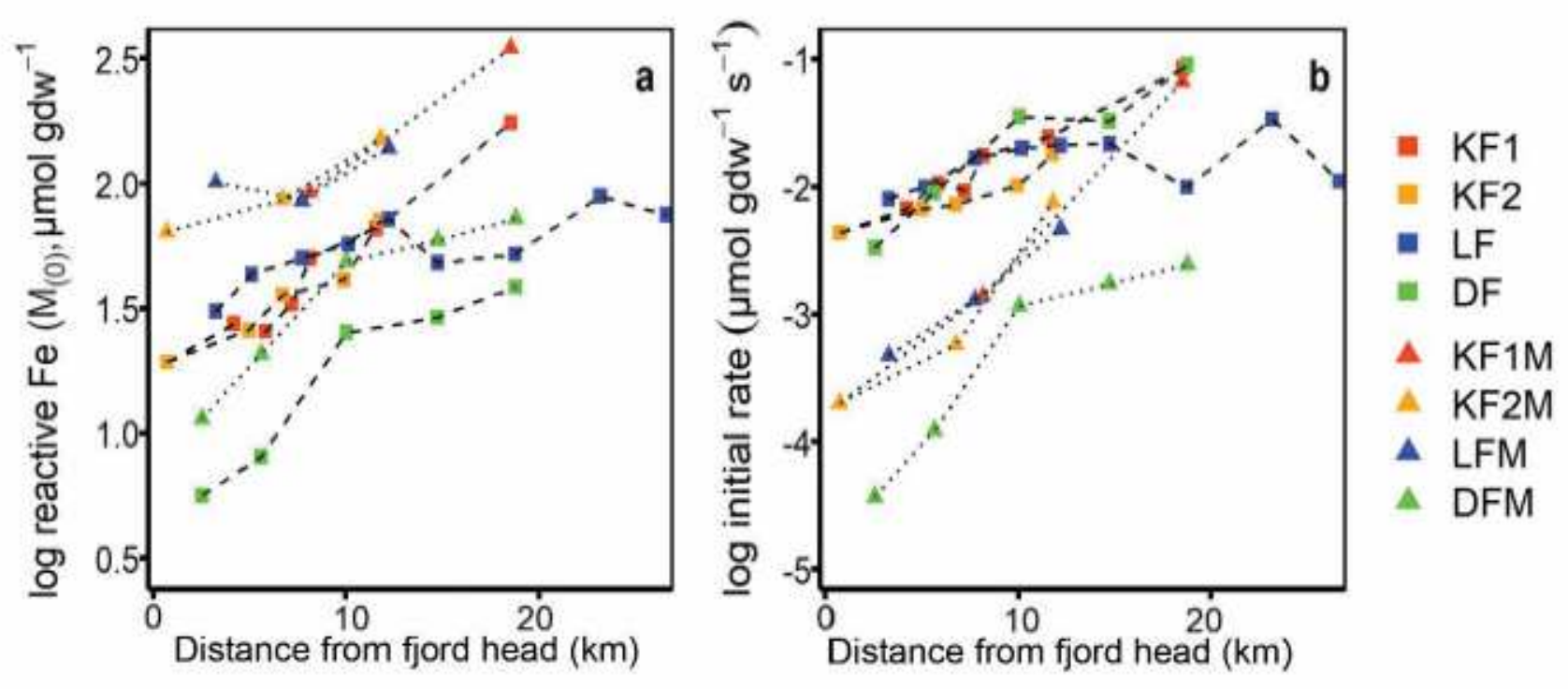

Figure 3

Amount $(\mathrm{M}(0))$ and reducibility (initial rate) of FeR versus distance from the fjord head. a and b amount $(M(0))$ and reducibility (initial rate), respectively, of the surface sediment as determined in AFeR (squares) and MFeR (triangles) extractions. 


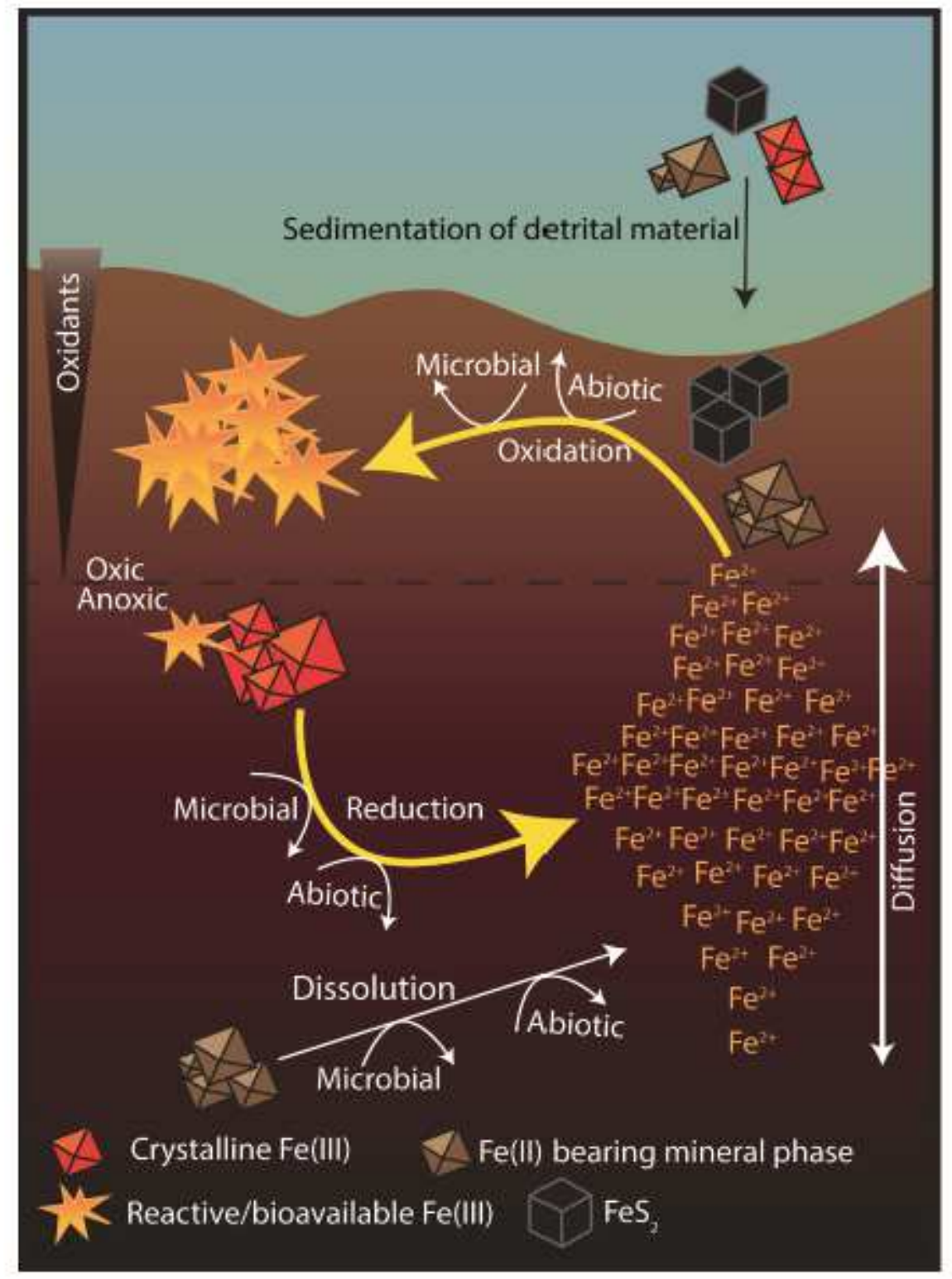

\section{Figure 4}

Schematic figure of how benthic iron cycling produces reactive iron at the oxic-anoxic interface in fjord sediments. 

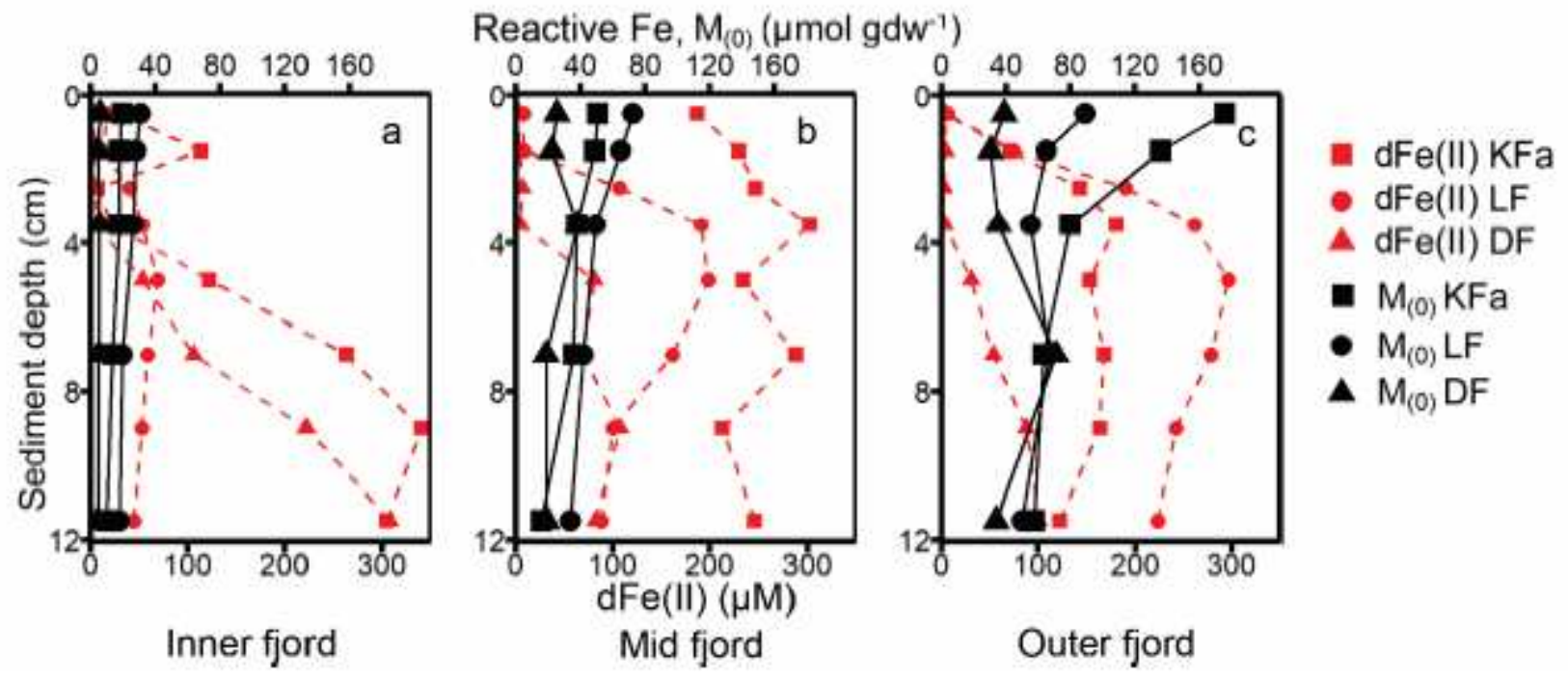

Figure 5

Concentrations of reactive iron, and dissolved iron and manganese over sediment depth at three stations within the transects. The three frames show the amount of reactive iron $(M(0)$, determined in AFeR extractions) and concentration of dissolved iron (dFe(II)) in the pore water versus sediment depth at a: stations closest to the fjord head (Kongsfjorden $=K F a 1$, Lilliehöökfjorden = LF1, Dicksonfjorden= DF1); $b$ : mid-fjord stations (Kongsfjorden $=\mathrm{KFa} 5$, Lilliehöökfjorden $=\mathrm{LF} 5$, Dicksonfjorden $=\mathrm{DF} 3$ ); and c: stations closest to the fjord mouth (Kongsfjorden $=\mathrm{KFa}$, Lilliehöökfjorden $=\mathrm{LF8}$, Dicksonfjorden $=$ DF5). 
$\mathrm{dFe}(\mathrm{II})$ and $\mathrm{dMn}(\mu \mathrm{M})$
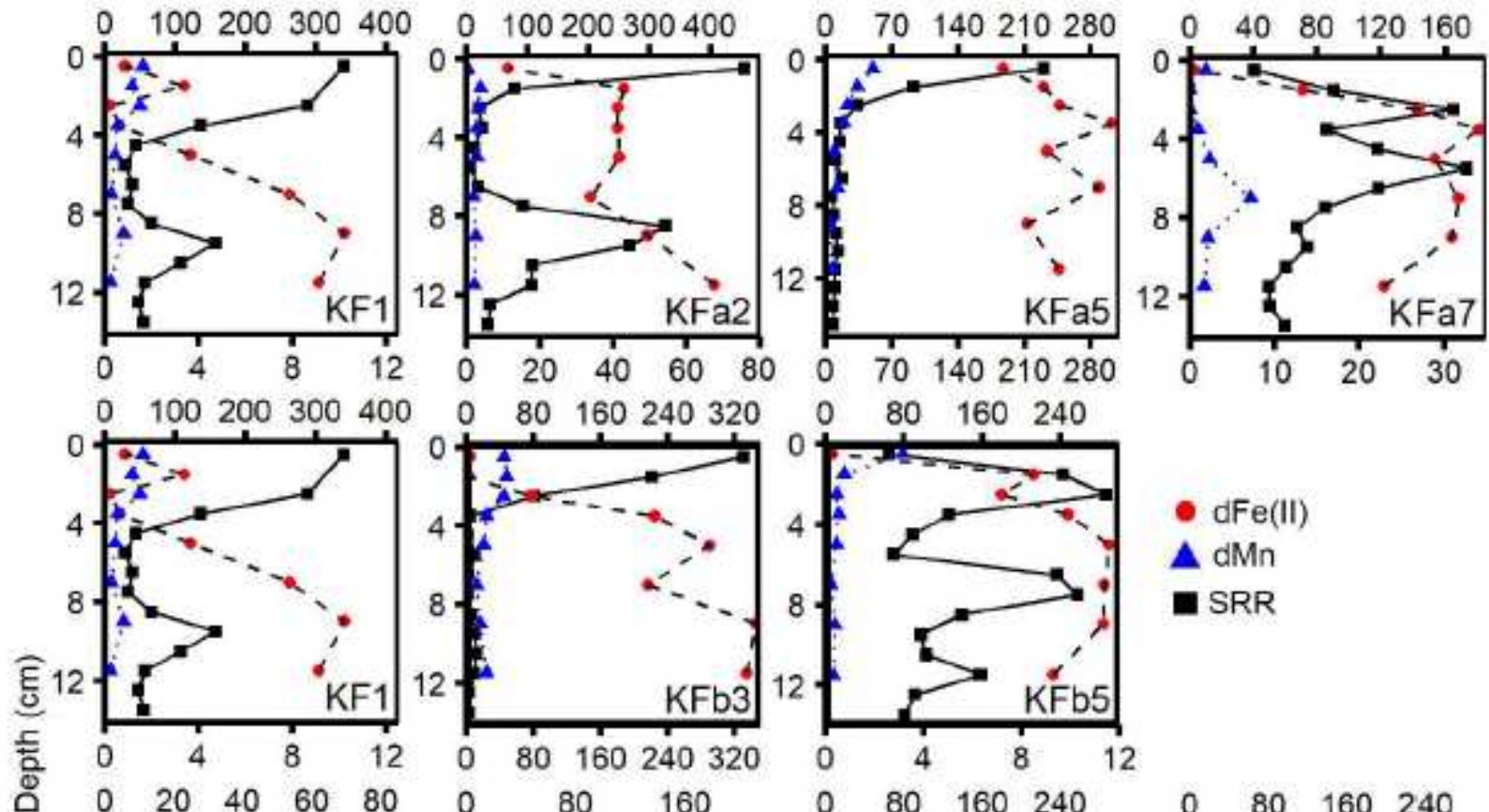
- dFe(II)
$\mathbf{A} \mathrm{dMn}$
- SRR
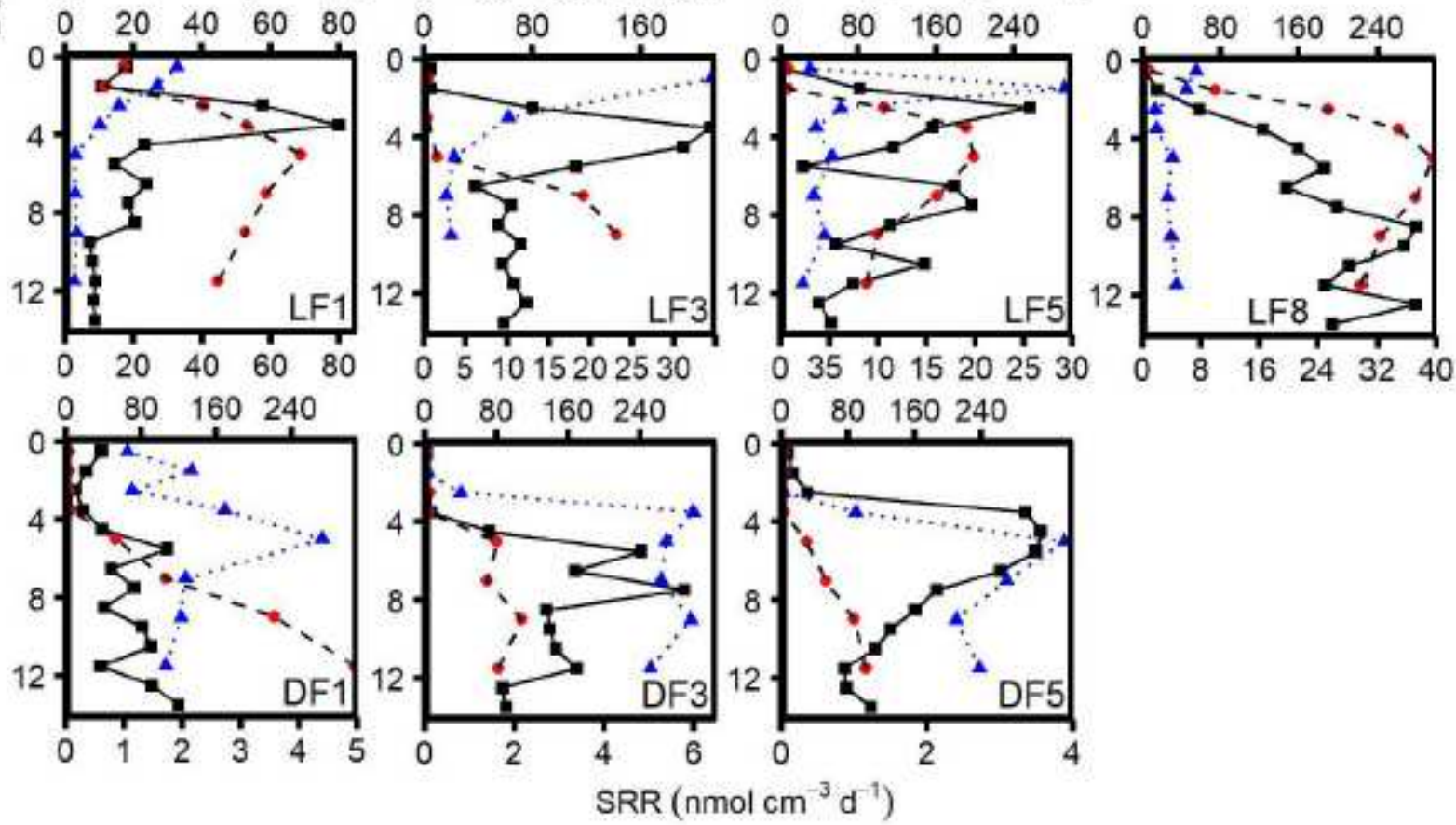

Figure 6

Pore water profiles of $\mathrm{dFe}(\mathrm{II})$ and $\mathrm{dMn}$ and distribution of sulfate reduction rates (SRR) at the main stations in all transects. 

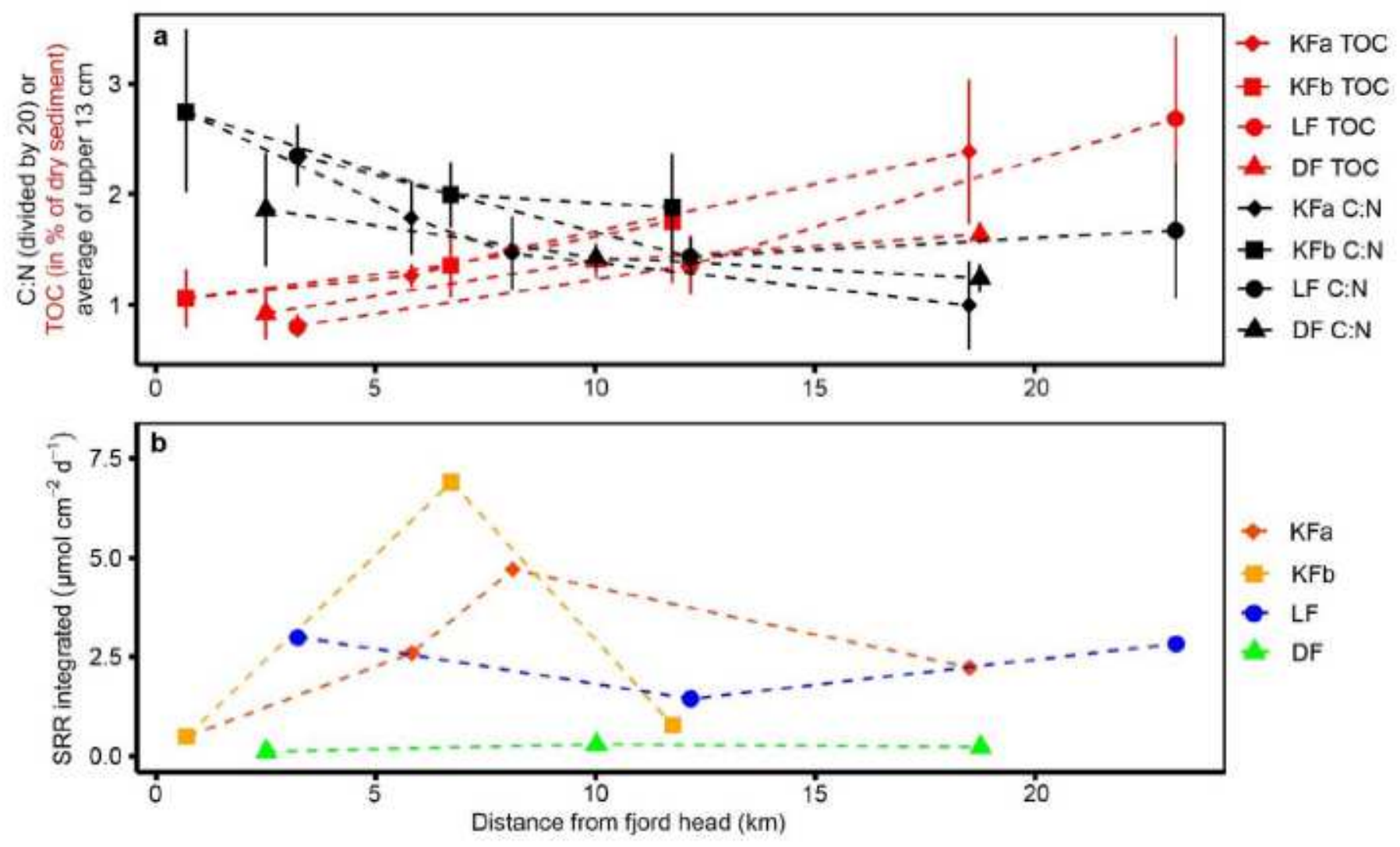

Figure 7

TOC, C:N and integrated SRR over distance from the fjord head. 


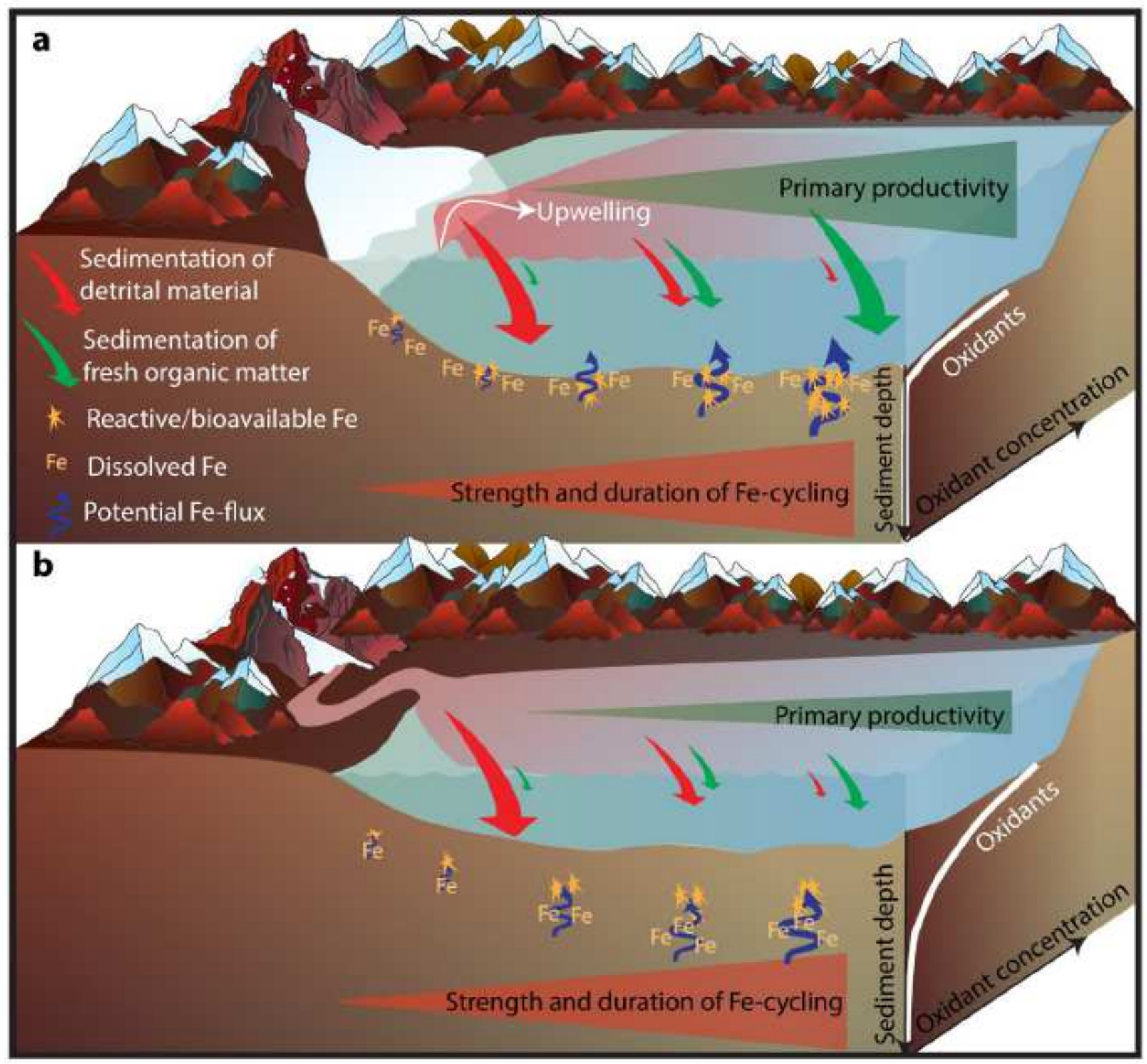

Figure 8

Schematic comparison of current (a, Kongsfjorden) and future (b, Dicksonfjorden) scenarios. The strength of the processes is indicated by symbol/arrow size. a: Fe cycling in a fjord with a marineterminating glacier and $b$ with a land-terminating glacier. Fe-cycling is impacted by the gradients of input of detrital material and fresh organic matter. Symbol descriptions in panel a also apply to panel $b$.

\section{Supplementary Files}

This is a list of supplementary files associated with this preprint. Click to download.

- LauferetalSupplements.pdf 